\title{
DNA Printing: The Unexamined "Witness" in Criminal Trials
}

\author{
Anthony Pearsall $\dagger$
}

DNA printing reseinbles a genetic blueprint. ${ }^{1}$ The process begins with the extraction of deoxyribonucleic acid (DNA) from cells in a tissue sample (for example, blood, skin, hair). A technician uses laboratory procedures to break up the DNA chain into smaller segments and to make a visual image of these segments. Since the existence and characteristics of these seginents create an individual pattern, the DNA print can be used like a fingerprint to identify or clear suspects by comparing the DNA prints. ${ }^{2}$

DNA printing, however, is potentially superior to fingerprinting and all other forins of forensic body material analysis currently in use: while other forensic analyses can only exclude possible suspects, or point to the mere likelihood of a suspect's involvement im a crime, DNA printing purports to show (to a dennonstrable probability of billions to one), that a particular suspect was involved in the crime in question. DNA printing can therefore furnish devastating evidence against a defendant, and an erroneous DNA print identification could cause the conviction of an innocent person. Because of its potentially decisive impact on the outcome of a trial, courts must scrutinize the quality and accuracy of this

$\dagger$ B.A., 1981, M.A., 1982, University of California, Berkeley; third year law student, Boalt Hall School of Law, University of California, Berkeley. The author wishes to thank the following people for their kind assistance: Kenneth Witts, Assistant Public Defender, and Kellie Nielan, Assistant Attorney General, both of Daytona Beach, Florida; Hon. Douglas Rutnik, Public Defender, Albany, New York; Kathryn Edgington Perry, former Chief, Office of Information and Public Affairs, California Dep't. of Health Services, Sacramento, California; Dr. Benjamin Grunbaum, Moraga, California; Professor Preble Stolz, Boalt Hall School of Law; and for her invaluable editing and comments, Karen Kennard.

1. A team of British scientists first reported DNA printing in 1985. The process was a byproduct of research in inolecular biology. Jeffreys, Wilson \& Thein, Hypervariable 'Minisatellite' Regions in Human DNA, 314 NATuRE 67, 67 (1985). The medical research institute with which Dr. Jeffreys is associated has patented his method and sold the rights to a major chemical concern that markets the test through the firm Cellmark Diagnostics.

2. Other authors lave thoroughly described the techniques of DNA printing with explanations tailored for non-scientists. See Thompson \& Ford, DNA Typing: Acceptance and Weight of the New Genetic Identification Tests, 75 VA. L. Rev. 45, 48-51 (1989); Burk, DNA Fingerprinting: Possibilities and Pitfalls of a New Technique, 28 JURIMETRICs J. 455, 456-67 (1988); Comment, DNA Identification Tests and the Courts, 63 WASH. L. REv. 903, 909-23 (1988) (authored by Laurel Beeler and William R. Wiebe). 
powerful new technology and guard against procedural unfairness to defendants. $^{3}$

DNA printing has been used in numerous criminal cases since its 1987 debut in the United States. In every federal and state jurisdiction, courts use either the Frye ${ }^{4}$ standard or the relevancy standard of evidentiary review to determine the admissibility of novel scientific evidence. ${ }^{5}$ This Comment shows that neither of these standards provides sufficient protection against the premature admission of forensic DNA printing when it is applied with insufficient rigor. Courts applying both standards have admitted novel scientific evidence later proven to be unreliable. Moreover, the Frye and relevancy standards are ill-equipped to address the difficult issues associated with the use of DNA prints. DNA print technology presents unusual problems involving quality assurance standards, fairness to criminal defendants, and concerns about individual privacy. Because admissibility hearings are not desigued to address these issues, courts have held forensic DNA printing admissible despite a lack of impartial scientific validation, without requiring uniform standards of practice for crime laboratories or procedural safeguards for defendants, and with no explicit consideration of privacy rights.

This Comment will argue that the current lax application of the two admissibility standards to DNA printing is unacceptable. It will therefore recommend that legislatures oversee the adoption of standards for DNA printing in criminal cases.

Part I of this Comment describes the DNA printing technique. Part II exposes potential flaws in the DNA print technology, and the dangerously high error rates experienced by the crime laboratories that eventually will perform DNA printing. Part III suggests that DNA print technology raises several unique fairness and privacy concerns that militate against rash acceptance of the techniques. Part IV argues that courts do not address these concerns effectively when applying the traditional admissibility standards. In addition, the admissibility standards, as applied in actual cases, have resulted in the premature admission of evidence in the past and the problem remains unsolved. Part V, therefore, advocates a comprehensive legislative approach at the state level to address the DNA adoption effort, preferably through uniform action.

3. This Comment does not criticize or question either the theory of DNA individuality or the particular techniques used to produce the prints (except to point to questions about their forensic effectiveness). The theory is scientifically unassailable, and the techniques clearly are reliable when testing fresh samples. Nor does this Comment discuss the civil applications of DNA printing, such as civil paternity testing, except when these applications threaten notions of individual privacy. Rather, this Comment focuses primarily on the concerns raised by forensic DNA printing.

4. Frye v. United States, 243 F. 1013 (D.C. Cir. 1923).

5. For descriptions of these standards, see infra text accompanying notes 79-116. 


\section{The Technology of DNA Printing}

All forensic identification methods aim to isolate physical qualities or traits that vary among individuals. The value of any particular method lies in its ability to individualize a subject. Fingerprinting is the paradigmatic example of such an identification technique. Fingerprints represent a particularly valuable means of identification because they are unique to each person and they can be easily fixed and read. ${ }^{6}$

The proponents of DNA printing liken it to fingerprinting. ${ }^{7}$ To test the accuracy of this analogy, the next sections examine the nature of DNA and the manner by which scientists fix and read its "impression."

\section{A. The Nature of DNA}

DNA, first discovered in $1869,{ }^{8}$ contains the chemically encoded genetic inforination that deternines each individual's physical makeup. ${ }^{9}$ It is found in virtually every cell of the body and may be extracted from, among other things, blood or semen and their dried stains, semen-free vaginal swabs, hair roots, and the lining of the mouth. ${ }^{10}$ In recent decades, scientists have made significant progress in identifying its structure and properties. Workers in genetics and allied fields have learned how to divide, manipulate, and even replicate DNA fragments.

A DNA print is alinost as distinctive as a fingerprint. Only identical twins have identical DNA. ${ }^{11}$ This high level of individuality permits criminal investigators to inculpate or exculpate a suspect by comparing his or her DNA print with those DNA prints derived from body fluids, hair or skin found at the crime scene.

But just as police might recover only a partial, or hopelessly smudged, fingerprint from the crime scene, they nuay be unable to

6. See, e.g., People v. Jennings, 252 Ill. 534, 546-49, 96 N.E. 1077, 1081-82 (1911). "The individuality of fingerprints is the most important aspect for human identification. Even identical twins have variations in their fingerprint patterns. To date, there are no two fingerprints known to exist that are duplicates unless they come from the same individual." L. MILLER, W. BASS \& R. MilleR, Human EvidenCE IN CRIMINAL JUSTICE 20 (1983).

7. See, e.g., Gill, Jeffreys \& Werrett, Forensic Application of DNA 'Fingerprints', 318 NATURE 577, 577 (1985); Jeffreys, Wilson \& Thein, Individual-Specific 'Fingerprints' of Human DNA, 316 NATURE 76, 77 (1985); Jeffreys, Wilson \& Thein, supra note 1, at 72.

8. A. Moenssens, F. Inbau \& J. Starrs, Scientific Evidence in Criminal Cases 35657 (3d ed. 1986).

9. See J. Watson, Molecular Biology of the Gene 255 (2d ed. 1970).

10. Gill, Lygo, Fowler \& Werrett, An Evaluation of DNA Fingerprinting for Forensic Purposes, 8 ELECTROPHORESIS 38 (1987).

11. Jeffreys, Wilson \& Thein, supra note 7, at 77. By contrast, one fundamental premise of fingerprint individuality is that "the patterns differ from individual to individual, and even from digit to digit, and are never duplicated in their minute details. ..." A. MoEnssens, F. INBAU \& J. STARRS, supra note 8 , at 421 . 
recover a usable source of DNA from it. DNA gradually degrades when it separates from the body, breaking apart into fragments that are too small to create usable DNA prints. ${ }^{12}$ This suggests the need to examine DNA printing technology closely in order to better evaluate the method's strengths and limitations.

\section{B. Capabilities and Shortcomings of DNA Printing}

The degree to which DNA printing can individualize a subject varies with the technique used and the condition of the sample. Under ideal conditions, the Jeffreys method ${ }^{13}$ can determine, to a claimed statistical probability of thirty billion to one, that the DNA print of a given individual is unique. ${ }^{14}$ Lifecodes Corporation, which markets a competing system, estimates that its method can individualize to one in $840,000,000 .^{15}$ A third contender, Cetus Corporation, makes far less sweeping claims for its technique. ${ }^{16}$

Additionally, the condition of the sample collected at the crime scene can affect the value of a DNA print. Degradation of DNA by aging, heat, and drying breaks up the DNA fragments and can render the DNA bands unreadable. For example, blood and semen stains kept at room temperature for periods of more than four years have not produced usable prints, ${ }^{17}$ and the "window period" for obtaining usable sperm from vagmal swabs has varied from two to forty-eight hours in controlled experiments. ${ }^{18}$ In one study, DNA prints could not be obtained from bloodstains stored for three or more days at $100 \%$ humidity. ${ }^{19}$

Proponents claim that a test that is performed incorrectly, or uses overly-degraded DNA, will not yield a false reading, but rather no reading at all. ${ }^{20}$ This overlooks the fact that the fragments do not all decay at

12. See Gill, Jeffreys \& Werrett, supra note 7, at $\mathbf{5 7 7 .}$

13. So called in honor of its inventor, Dr. Alec Jeffreys of Great Britain. Cellmark Diagnostics offers it commercially in the United States. Thompson, DNA Fingerprinting: Who Does It and How, Cal. LAw., June 1988, at 41.

14. Gill, Jeffreys \& Werrett, supra note 7, at 579 .

15. The figure is for white Americans. Lifecodes claims a one in 1.4 billion probability of identification for black Americans. People v. Wesley, 140 Misc. 2d 306, -, 533 N.Y.S.2d 643, 652 n.14 (Co.Ct. 1988).

16. Thompson, supra note 13. Despite their lower individualization statistics, the promoters of the Cetus method argue that their technique is sufficientiy accurate to incriminate or exculpatc a subject in conjunction with other evidence. Id.

17. Gill, Jeffreys \& Werrett, supra note 7, at 578. The authors used the Jeffreys method.

18. Gill, Lygo, Fowler \& Werrett, supra note 10 , at 41 . This experiment tested the Jeffreys method.

19. Id. at 42 .

20. See, e.g., Upstate Judge Orders Genetic Fingerprints, N.Y.L.J., July 27, 1988, at 1, col. 7. But see Thompson \& Ford, DNA Typing, TRlal, Sept. 1988, 56, 62-63:

The likelihood of a coincidental misidentification ... depends, in part, on the characteristics of the genetic probe used to locate the polymorphic DNA segments ... . To date, few genetic probes have been found that can reliably distinguish individuals. Among 
the same rate. A decayed DNA sample can provide some visible bands, although less than the optimal number for printing. As the number of visible bands declines, so does the probability of uniqueness. ${ }^{21}$ Moreover, the amount of sample material needed varies with the technique used. For example, the Jeffreys and Lifecodes methods require several hundred thousand spern heads (which may be obtained from less than a teaspoon of semen) or a bloodstain the size of a quarter for reliable results, and tests based on smaller samples often yield inconclusive results. ${ }^{22}$ The Cetus method uses a patented gene amplification technique that requires far less sample materials. ${ }^{23}$ Tests based on decayed or insufficient DNA samples prevent significant risks of producing non-unique prints that inay be used to wrongly mculpate an innocent person.

The "human element" involved in print analysis provides another shortcoming of DNA print teclinology. Although DNA's proponents tend to mimimize the risks of human error, variations in the execution of simpler forensic tests are known to affect their results, ${ }^{24}$ and it is likely that similar error will plagne DNA printing. Moreover, the DNA print, once obtained, must be interpreted by an analyst and compared with other prints to determine whether there is a match. While DNA prints are not especially comphcated in appearance, the interpretation of band position, size, and definition requires trainmg and individual judgment. ${ }^{25}$ Since forensic DNA samples are apt to have fewer and fainter bands than

those that reportedly have this property, most are patented and have been studied only by their corporate owners.

Assuming [reliable probes] . . DNA typing may [still] produce a misidentification. First, two people may have an identical DNA type (i.e., identical DNA prints or alleles). DNA prints are not necessarily unique to a given individual. While [only identical twins] have the same DNA, two unrelated people may have identical prints because they happen to have polymorphic DNA segments of the same length.

21. See Werrett \& Lygo, DNA Profiling, 84 LAw Soc'Y's Guardian GazeTte 3637, 3643 (1987).

22. Thompson, supra note 13. Small though such quantities may seem, a leading criminologist has noted that they are more than most investigations recover. Id.

23. This technique is called the "Polymerase Chain Reaction (PCR)" method. See Thompson \& Ford, supra note 2, at 76-77.

24. See, e.g., von Beroldingen \& Sensabaugh, Forensic DNA Analysis, 12 TIELINE 27, 42 (1987) (an internal publication of the Bureau of Forensic Services, California Dep't of Justice).

25. Id. See Thompson \& Ford, supra note 20, at 62-64:

Similar but not identical DNA prints may, as a practical matter, be indistinguishable because within certain ranges electrophoresis gels have "poor resolution" (i.e., DNA fragments of widely different lengths may produce bands that are close together) . . . . Hence, just as it may be difficult to distinguish between similar-looking people in blurry photographs, it may be difficult for an expert to distinguish between different DNA types.

[Random variations in the patterns of the bands are also possible.]

Consequently, an expert who insists that DNA prints be identical in all respects before declaring that they match is going to miss a lot of matches. To the extent the expert is willing to declare a match when two DNA fingerprints are similar but not precisely identical, however, the risk of a false identification increases. Id. at 63-64. 
those made from fresh samples, the individual judgment of the forensic analyst is even more critical than in nonforensic studies.

Several factors interact to affect the extent to which the DNA printing process can individualize a subject. The next part will discuss independent validation of the reliability of the various printing methods and the difficulties inherent in assuring proper testing procedures.

II

\section{Application of DNA PRINT Technology: Reliability AND PERFORMANCE}

In addition to the limitations presented by the technology itself, forensic DNA printing suffers from both the lack of validation by truly independent scientists and from uneven standards of quality control in its application. This part will examine the level of current knowledge about forensic DNA printing's reliability and will address the problem of quality control in crime laboratories-a problem which predates the invention of DNA printing and now threatens to compromise the new technique.

\section{A. Reliability}

The reliability of a scientific test refers to "whether the same results are obtained in each instance in which the test is performed-its consistency."26 Clearly, any scientific technique that provides evidence against a criminal suspect should meet a high standard of reliability. This high standard becomes even more important in DNA printing, because the technique holds out the promise of positive identification of crime suspects. Yet scientists have particular difficulty ascertaining the reliability of forensic tests. ${ }^{27}$

The forensic scientist faces unique analytical challenges that pose significant threats to reliability. For example, the forensic examiner may work with a bloodstained garnent found in the closet of the suspected

26. Giannelli, The Admissibility of Novel Scientific Evidence: Frye v. United States, a HalfCentury Later, 80 Colum. L. Rev. 1197, I201 n.20 (1980).

27. The following exchange from a murder trial record shows just how difficult it can be to reliably evaluate forensic science tests:

THE COURT: My problem is that unless I misunderstand (the expert witness), he is telling me that no one, to his knowledge, has ever studied the process of degeneration of semen deposited in a dead body, or a body that became dead shortly after the deposit. THE WITNESS: That is correct, because it's a very difficult experiment to even consider. I mean, you have to get somebody to die for you. And before they die, you have to put semen into the body and then say, okay, we will leave it, you know, ten hours and twenty hours and thirty hours, now you have to die. It's an almost impossible experiment to consider.

Grunbaum, Problems Inherent in the Analysis of Rape Evidence-State of the Art, 13 CAL. ATT'Ys FOR CRIM. JUST. F. no. 5, at 30, 37 (1986) (italics omitted). The colloquy comes from a hearing in People v. Carpenter (Los Angeles Sup. Ct., No. A-379894, v. 90, p. 13,502 (June 21, 1984)). 
killer. The murder occurred years ago, and the garment may have lain on the suspect's back porch in high humidity for several months before being tossed into the closet. The bloodstain inay be small, and its history may be unknown. ${ }^{28}$ Such conditions are antithetical to those in the clinical laboratory setting where scientists analyze fresh, hygienic, and relatively unlimited amounts of DNA.

Further, the necessary einpirical proof of a forensic test's accuracy and reliability should coine from independent researchers. In the case of DNA printing, this is more the exception than the rule. Government scientists, primarily those of the British Home Office, have published a few studies of DNA printing under forensic conditions. ${ }^{29}$ In 1988, however, the head of the Federal Bureau of Investigation's serology unit admitted: "We've only done a himited number of tests yet. So we can't say with absolute certainty that [the technique] works on different sizes of stains, aged stains, [or] putrefied stains." ${ }^{30}$

Scientists associated with the different DNA printing methods have published a few reports on the forensic use of the test. ${ }^{31}$ Scientists from Lifecodes Corporation, currently the most ubiquitous proponent of forensic DNA printing in the United States, have published articles discussing trials of their technique under modest simulations of forensic conditions. In one experiment, ${ }^{32}$ they applied fresh blood to a cotton shirt and produced stains of about one and three quarter inches in diameter, which they aged at norinal room temperature for up to twenty-eight days. They also tested three postmortem blood stains on cloth that had been kept in a cold room for two to three years. The tests produced readable DNA prints, but the authors of the report qualified their conclusions by noting that " $t \mathrm{t}] \mathrm{he}$ conditions in this report are more controlled than those hikely to be encountered in the field. Further work to investigate the effect of a variety of environmental factors on DNA recovery from bloodstains is in progress." ${ }^{33}$

28. The quality of a rape semen sample is affected by such ambient factors as dilution by vaginal fluids, rate of vaginal discharge, and steady internal degradation. See, e.g., Gill, Lygo, Fowler \& Werrett, supra note 10, at 39-41.

29. See, e.g., supra notes 18-19 and accompanying text. The Home Office is the British cabinet ministry responsible for, among other things, the police, the criminal justice system, and the forensic science service. WHITAKER's ALMANAC 400-01 (1988).

30. Thompson, DNA's Troubled Debut, CAL. LAw., June 1988, at 36, 44. In December, 1988, however, the FBI decided to begin using DNA printing in its own laboratories. The Bureau chose to use its own blend of the DNA probes and technologies employed by the commercial laboratories, for which it need pay no royalties. Watson, FBI Adopts DNA Test at Pioneer's Expense; Firm Must Find New Markets, Legal Times, Mar. 27, 1989, at 1, col. 3.

31. See, e.g., articles cited supra note 7 and infra notes $32 \& 34$.

32. Kanter, Baird, Shaler \& Balazs, Analysis of Restriction Fragment Length Polymorphisms in Deoxyribonucleic Acid (DNA) Recovered from Dried Bloodstains, 31 J. ForENSIC SCI. 403, 404 (1986).

33. Id. at 407. 
In a second experiment, Lifecodes scientists tested semen samples obtained from vaginal swabs and from stains lifted from undergarments and sanitary napkins. ${ }^{34}$ The conditions of the test were relatively controlled, however, as no stams had aged more than seven days. This experiment also produced readable DNA prints, although the authors again qualified their conclusions by observing that "the persistence of DNA in a dried semen stain is unknown . . .."35

The other two commercial laboratories have offered even less information about the reliability of their methods of forensic testing. Other than initial reports about the Jeffreys method following its invention, Cellmark Diagnostics has published little material validating its forensic test. Nor will Cellmark release its patented technology for outside use, which naturally hampers independent testing of Cellmark's reliability claims. ${ }^{36}$ The Cetus Corporation has never published detailed reports on the reliability of its forensic technique, and it insists on not releasing details of its patented process for use outside its laboratory at this time. ${ }^{37}$ Independent verification of forensic DNA printing's reliability is clearly necessary.

Unfortunately, validation alone will not solve the problem. Any test, no matter how thoroughly validated, becomes unreliable when performed unreliably. Concern about test conditions will persist long after questions of basic reliability have been laid to rest, because misuse undermines the dependability of even sound technology. The next section, therefore, explores problems of crime laboratory performance.

\section{B. Performance}

In the popular imagination, crime laboratories enjoy an aura "of mystic infallibility." ${ }^{38}$ In recent years, however, large-scale proficiency tests conducted by the Forensic Sciences Foundation reveal that the rate of erroneous identification, even for established forensic tests such as hair and ballistics identification, is disturbingly high. ${ }^{39}$ Consequently, courts cannot presume the reliability of analyses performed by crime laboratories.

34. Giusti, Baird, Pasquale, Balazs \& Glassberg, Application of Deoxyribonucleic Acid (DNA) Polymorphisms to the Analysis of DNA Recovered from Sperm, 31 J. FoRENSIC ScI. 409, 410 (1986).

35. Id. at 413-14. The authors think, however, that DNA would last at least a month in dried semen.

36. Thompson, supra note 13.

37. Id.

38. "[S]cientific proof may in some instances assume a posture of mystic infallibility in the eyes of a jury. ..." United States v. Addison, 498 F.2d 741, 744 (D.C. Cir. 1974).

39. See, e.g., E. IMwinkelried, The Methods of ATtacking Scientific Evidence 5-6 (1982) (describing failure rates in numerous categories, discovered by proficiency testing). 
Crime laboratory performance of electrophoresis testing to determine genetic markers in physiological stams is particularly relevant to the DNA printing debate because of the operational similarities between the two methods. ${ }^{40}$ The results of a recent proficiency test ${ }^{41}$ are disturbing. Testers sent two sainple stains made with fresh, whole human blood to 123 laboratories for analysis. The labs were to type the bloodstains using their normal procedures. As the report noted, "this test was a straightforward examination with no case type scenario [and presented] the laboratories with the opportunity to demonstrate their proficiency on clean, fresh, uncomphicated samples." 42 Of the sixty-eight laboratories that returned results, sixteen (23.5\%) were in error on one or both samples. ${ }^{43}$ This error rate would prove unacceptably high in the context of DNA print analysis.

High error rates form only one part of the quality control problein. In addition, unlike clinical laboratories and blood banks, forensic laboratories need no certification to operate. ${ }^{44}$ Control over crime laboratories typically is split, even within a single state. State, county, municipal, and private laboratories may operate autonomously. ${ }^{45}$ A private forensic laboratory typically is not subject to government regulation, inspection, or licensing with respect to performance standards. ${ }^{46}$ Governmentoperated crime laboratories set their own standards; there are accrediting

40. Electrophoresis is the laboratory process of separating molecules by size and weight in an electronically charged medium-usually a gel. Scientists have used this process for a number of years to analyze physiological fluid samples, especially semen and blood, for "genetic markers" various proteins found in the fluids, the polymorphism of which varies from one person to another. These tests are commonly referred to as "electrophoresis" or "blood typing" tests. See L. MILLER, W. BASS \& R. Miller, supra note 6, at 45 .

An electrophoresis procedure is a central step in DNA printing. In both "traditional" electrophoresis and DNA printing, operators analyze the visible "bands" that are the final result of the processes, to make comparisons and identifications. Hence, difficulties in correctly performing and analyzing "traditional" electrophoretic examinations foreshadow failures in DNA printing.

41. Collaborative Testing Services, Inc., Crime Laboratory Proficiency Testing Program, Physiological Fluids analysis Report No. 87-2 (1987).

42. Id. at 1 .

43. Id. Interestingly, an examiner with eight years of experience in serology made the largest number of errors. Id. at 26-27.

44. "[Government crime laboratories] share no codified standards of practice. . . [Private] laboratories are subject to no external quality control whatsoever. They are not licensed nor are they subject to supervision, inspection, or mandatory proficiency testing." Grunbaum, Physiological Stain Evidence: Guidelines to Assure Quality Analysis, 1 CAL. DEFENDER no. 1, 20, 24 (1985); see also Giannelli, The Admissibility of Laboratory Reports in Criminal Trials: The Reliability of Scientific Proof, 49 OHIO ST. L.J. 671, 690 (1988) (citing studies which show lack of externally imposed and monitored quality standards for most forensic laboratories).

45. For example, in 1986 California had thirteen state crime laboratories, eleven county crime laboratories, and eight city police crime laboratories. The city and county crime laboratories were autonomous, as were the six or seven private laboratories. Grunbaum, supra note 27, at 30. The FBI also has its own forensic science department. Federal Bureau of Investigation, HANDBooK of Forensic SCiEnCE 5, 30 (1984).

46. See Grunbaum, supra note 44 , at 23-24. 
organizations, but accreditation is voluntary. ${ }^{47}$ Quality control in American crime laboratories remains on the honor system.

The crime laboratories' diversity of procedure reflects this disunity. For exainple, individual laboratories, and even individual technicians, frequently set their own idiosyncratic standards concerning testing protocols for the same basic serological test. ${ }^{48}$ Variation of protocols ("Protocol Drift") may cause mconsistent test results. Especially troublesome, the interpretation of test results may represent only one analyst's opinion..$^{49}$

Finally, while many laboratory technicians are hardworking, dedicated, and capable, there are some who are sinuply incompetent. ${ }^{50}$ For exainple, in the 1979 Illinois trial of Gary Dotson for the rape of Cathleen Crowell Webb, a state "forensic scientist" testified that according to a genetic marker test he performed, Dotson was one of only $10 \%$ of Caucasian men who could have been the source of the semen found on her panties. Years after Dotson had gone to prison for the rape, Webb recanted her story. To bolster their claim that Dotson was guilty, authorities retested the seinen, using the saine test, but a different operator. The retest showed that two-thirds of the white male population could have been the source of the semen. ${ }^{51}$ Without the special circumstance of the recantation, this error in a routine rape case probably never

47. While there may be no studies discussing the accreditation issue among government crime laboratories alone, it is possible to draw inferences from available statistics. Most crimc laboratories are operated by state, county, or local governments. By 1983, there wcre over 300 crime laboratories in the United States, up from approximately 100 in 1968. Giannelli, supra notc 44, at 690 . As of 1987, only 51 laboratories were accredited by the fivc-year-old voluntary accreditation program of the American Society of Crime-Laboratory Directors. Id. at 690-91 n.163 (citing FEDERAL Bureau of Investigation, Crime Laboratory Dig. 37 (Apr. 1987). Even if all of the accredited laboratories were governmental, some government laboratories would be unaccreditcd. Apparently, many or most government crime laboratories have only internally-imposed quality controls or, at best, system-wide controls which might govern a network of state laboratories.

48. See, e.g., Bretz, Scientific Evidence and the Frye Rule: The Case for a Cautious Approacl, 4 Cooley L. REv. 506, 518 (1987) (describing expert witness' admission that no uniform procedure for electrophoresis exists in crime laboratories and that examiners routinely modify techniques for their convenience). The California Department of Justice inadvertently demonstrates this disunity by instructing its forensic tcchnicians that "a pre-set list of minimum performancc standards does not apply to forensic science where the individual skill, judgment, and experience of the scientist [that is, the laboratory technician] are the final determiners of what specific tests arc requircd in each instance." State of California, Department of Justice, Bureau of Forensic Services, TechNical Guidelines 85-1 Serology 1 (1985) (quoted in Grunbaum, supra notc 27, at 31).

49. Moreover, adequate test records are neither consistently generatcd nor preserved. Again, the adequacy of record-keeping varies from facility to facility, and examiner to examiner. See, e.g., People v. Seda, 139 Misc. 2d 834, 529 N.Y.S.2d 931 (N.Y. Sup. Ct. 1988) (electrophoresis examiner [Dr. Robert Shaler] in the office of the Chief Medical Examiner, New York City, who made no recordings of timing, temperature, and voltage during the process, took no photographs of, and did not preserve the clectrophoretograms in a murder case, testified that he "acted as his own quality control"). Id. at 841,529 N.Y.S.2d at 935 .

50. See, e.g., Bretz, supra note 48 , at 518-20.

51. Thompson, supra note 30 , at 43 . 
would have come to liglit. ${ }^{52}$ Sucli imcompetence, in conjunction witl variance in lab procedures and a lack of central supervisory authority, results in an endemic rate of failure in the performance of identification tests.

These independent and often unreliable crime laboratories will soon begin to assume responsibility for DNA printing. Lifecodes, for example, will market its test in "kit" form to local crime laboratories, to perform their own tests. ${ }^{53}$ Altlouglı Cetus and Cellmark Diagnostics so far have kept their testing in-house, that practice will not remain feasible when the demand for DNA print analysis reaches liundreds of thousands, and perhaps inillions, of tests per year. ${ }^{54}$ In preparation for this demand, Cetus is 1narketing its licensed hardware and software. ${ }^{55}$ Many crime laboratories will, therefore, be performing DNA tests in the near future under licensing agreements. The performance standards of these laboratories is, in many cases, open to question, or unknown.

A mandatory quality assurance program should be in place before this proliferation of DNA printing laboratories occurs. DNA printing is a "time-consuming and somewhat tricky" procedure, ${ }^{56}$ requiring the analysis of a "complex" and sometimes "difficult to interpret" band pattern. ${ }^{57}$ Unless the courts or the legislatures establish umiform procedures for DNA printing in crime laboratories, human error will infect this process to an unacceptable degree. Proposed standards need to be adopted

52. The prosecution now says that: "you don't need semen to prove [that] a rape occurred." Dotson Cites Test, Seeks a Full Pardon, Chicago Tribune, Oct. 9, 1988, § 2, at 1, col.1 [hereinafter Dotson Cites Test].

53. Thompson, supra note 13 .

54. "'In forensic testing alone,' said Cetus executive vice-president and COO, Hollings C. Renton, 'the firm's licensed PCR system . . . should be performing five-million tests worldwide, at $\$ 15$ each by 1990, up from 200,000 in '89 at \$ 50.'" Cetus to Exact Royalties from PCR Sales: Probe Absolves Convicted Rapist, 8 McGraw-Hill's Biotechnology NewswatCh, No. 17, at 7 (1988) [hereinafter Cetus Royalties].

Noting that Lifecodes would begin selling forensic DNA printing kits in January 1989, a Lifecodes manager, Dr. Robert Shaler, stated that the kits would cost in the neighborhood of $\$ 50$, while analyses done at the lab cost $\$ 325$ - "and we're not making any money on that. . . It's better from a businessman's point of view to be on the supply side, than service." New York State Considers Legislating DNA-Fingerprinting for Forensics, 8 MCGRAw-HILI's BIOTECHNOLOGY NEWSWATCH, No. 20, at 8 (1988).

A reporter detailing the "peddling" of DNA print technology to the legal community noted that Cellmark Diagnostics and its major competitor Lifecodes "frequently work in tandem," in promoting the technology generally. Lifecodes officcr Dr. Michael Baird stated that: "We have testified in cases Cellmark has done, and they've done the same in some of our cases. . . . We help bolster each others' testimony. It's a win-win proposition." "Watson, supra note 30.

55. Cetus Royalties, supra note 54.

56. von Beroldingen \& Sensabaugh, supra note 24 , at 36.

57. Id. 
and enforced before DNA printing joins the mainstream of forensic testing. Stringent, enforceable quality assurance guidelines will help inspire confidence in the consistency and accuracy of DNA print analysis. ${ }^{58}$

In addition to the uniquely problematic validation and performance concerns that DNA printing raises, the technology also presents a potential threat to the procedural rights of criminal defendants and the privacy rights of all individuals. Any regulations for DNA testing must give extensive consideration to necessary protections for both criminal defendants and the general public. Part II will discuss these fairness and privacy issues.

II

FAIRNESS AND PRIVACY

DNA print technology threatens to infringe on constitutionally guaranteed rights to procedural due process and individual privacy. Potential due process concerns include the availability of the test to indigent defendants, the creation of a prosecutorial duty to share test information with defense counsel, and the responsibility of authorities to preserve adequate amounts of material for testing or retesting by opposing counsel.

DNA printing's ability to transmit distinctive genetic information poses a potential threat to individual privacy. While use of the technique may be justifiable in the forensic context, state agencies, private companies, and individuals may devise applications of the technology that are potentially invasive of personal privacy.

\section{A. Fairness to Criminal Defendants}

The introduction of a novel and powerful technique raises several issues of fairness to criminal defendants. For some defendants, access to

58. Some forensics practitioners, recognizing the need for reform of crime laboratory procedure, have recommended adoption of voluntary quality assurance guidelines and accreditation schemes. Their peers have not responded positively: in 1979, crime laboratory personnel overwhelmingly defeated a proposal which would have created a voluntary "peer review" certification program, providing for baseline education and training requirements, written examinations, and proficiency tests for criminalists in all specialties, including forensic serology. Note, The Admissibility of Electrophoretic Methods of Genetic Marker Bloodstain Typing Under the Frye Standard, 11 OkLA. CITY U. L. Rev. 773, 809-10 (1986) (authored by David D. Dixon). Most forensics examiners oppose outside inspections, particularly if the inspecting authority has enforcement power.

Crime laboratories go to some lengths to keep their weaknesses hidden. For example, the voluntary proficiency testing program described supra, at text accompanying notes $41-43$, is entirely confidential; the control system ensures that not even the managers and "graders" of the program know which laboratory has returned which sample. See Collaborative Testing SERvices, Inc., supra note 41 , at 1 . 
test information may be vital, because they want to attack the test performance or results; for others, access to the test itself will be vital, for they will want to use it to prove their innocence. In order to preserve the constitutionally guaranteed right to a fair trial, both needs must be met. ${ }^{59}$

\section{DNA Printing for the Indigent Defendant}

Criminal defendants, not subjected to DNA printing by investigators, may wish to use DNA print comparisons to exonerate themselves. Coinmercial laboratories serve prosecutors and defendants alike, but DNA printing currently costs $\$ 200-\$ 300$ per individual sample tested and thus may be "unavailable" to indigent defendants. ${ }^{60}$ Existing case law argues that indigent defendants should be entitled to free DNA printing at a facility of their choice.

The Supreme Court's ruling in Ake v. Oklahoma ${ }^{61}$ strengthened the constitutional right of indigent defendants to free "expert services" in order to preserve their right to a fair trial. The Ake decision concerned an accused murderer's right to the services of a psychiatrist in framing his insamity defense, but the holding may be reasonably interpreted to recognize a right to all necessary expert services on a showing of indigency. ${ }^{62}$ Similarly, in Little $v$. Streater, ${ }^{63}$ the Court declared that an indigent putative father had a due process right to a free blood test in a paternity action. Read together, Ake and Little suggest that indigent defendants who demonstrate a valid need (determined by the court on the basis of relevance to the planned defense, as in $A k e$ ) for DNA printing services have a constitutional right to free testing by a "neutral" laboratory; that is, not the government's crime laboratory, and not a commercial laboratory if that laboratory is the one which performs tests for the jurisdiction in lieu of the government's own personnel. ${ }^{64}$

59. British commentators have questioned whether the DNA printing procedure is fair to defendants. Tests are performed either by Cellmark Diagnostics, a commercial laboratory, or by the Home Office, whose forensic service conducts the test for the British police forces. White \& Greenwood, DNA Fingerprinting and the Law, 51 MOD. L. REv. 145, 153-54 (1988). A British attorney has observed that "it is unfortunate that at present there is no aiternative laboratory available [for retesting]." Sookias, Genetic Fingerprinting: Degree of Caution, 85 LAW Soc'Y's GAZETTE, No. 6, at 8 (1988). At least one British biochemist, however, has announced his readiness to work as a consuiting expert for defendants in reviewing test results. Id.

60. Thompson, supra note 13.

61. 470 U.S. 68 (1985).

62. See Note, Expert Services and the Indigent Defendant: The Constitutional Mandate of Ake v. Oklahoma, 84 Mich. L. REv. 1326, 1362 (1986) (authored by John M. West).

63. 452 U.S. 1 (1981).

64. DNA printing may be provided free of charge to indigent defendants in England. Gold, DNA Explosion, 137 NEw L.J. 1104, 1104 (1987) ("Fees [for testing] are payable in advance to Celimark except in legal aid eases provided that a copy of the legal aid ... certificate is supplied .... The Law Society's legal aid headquarters has not formulated any official policy on approval for 


\section{Sharing of Information}

In order to permit defense counsel an opportunity to rebut the results of a DNA primting, the prosecution should have a duty to share all information regarding its DNA print testing with the defense. Prosecutors should be required to provide the final result with a copy of the primt, all examiner's notes, and any other information pertaining to the test procedure itself. This exchange of information does not consistently happen with other forensic tests. ${ }^{65}$ This information will assist defense counsel to more effectively plan the conditions to be followed on a retest, the arguments to make at a pretrial in himine hearing concerning exclusion of this evidence, or cross-examination strategies.

\section{Preservation of Sample Material for Retesting by Opposing Counsel}

Attorneys desiring to retest evidentiary specinens may find that the opposition's tests have used up all of the sample material. To prevent this, investigators must save enough material to allow the opposing side to perform its own test of the sample.

This duty, if it exists, ${ }^{66}$ will most often affect criminal prosecutors: defendants will seldom possess specimens that the prosecution would like to test but does not have. The preservation requirement should nevertheless be reciprocal.

These procedural issues chiefly concern participants in the criminal justice system. Unlike most forensic techniques, however, use of DNA printing threatens the privacy rights of ordinary citizens-beyond the more predictable civil applications in paternity suits and immigration proceedings.

\section{B. The Threat to Privacy}

DNA technology presents a potential for abusive intrusion into the privacy of ordinary citizens that other forensic tests do not. DNA can tell the knowledgeable examiner anything that can be read from an individual's genes, including farmilial relationships and predisposition to certain diseases. ${ }^{67}$ Examiners who publicly reveal such information, or

DNA testing in the course of proceedings although a number of [authorizations] have been given by area offices in appropriate cases.").

65. See, e.g., Bretz, supra note 48, at 518-20 (in murder trial, the only laboratory report turned over to defense counsel was a three-page summary of results; a freedom of information request produced nine pages of bench notes and photographs which revealed significant discrepancies with the expert testimony at the trial).

66. The Supreme Court recently cast doubt on the extent of such a duty. In Arizona y. Youngblood, 109 S.Ct. 333 (1988), the Court rejected a defense argument based on the police's destruction of semen samples gathered as physical evidence. Apparently, the Court regards such destruction as pardonable if it results from negligence rather than "bad faith."

67. There are over 4000 known single-gene hereditary illnesses. Gene mapping projects now 
simply possess it without the subject's consent, invade the subject's privacy. ${ }^{68}$

Law enforcement agencies, meanwhile, are beginning to plan identification databases that will compile individual DNA patterns for ready retrieval by imvestigators, and it will soon be feasible to establish a general identification system based on the DNA print. Such a DNA print bank would give unprecedented access to any information that could be determined from an individual's genetic code ${ }^{69}$ In sum, the potential for abuse of this powerful new technology by governments and private industry necessitates safeguarding individual privacy as part of an overall strategy to regulate the technique.

The British experience with DNA printing illustrates problems relevant to the issue of individual privacy, and furnishes a useful analogy for Americans to consider. The British used a voluntary mass-testing program in their 1987 investigation of two rape murders. Significant social pressure to submit to testing apparently existed, and over 5000 males in the small commumity's target age group provided blood samples. Only two refused, one of them the man eventually convicted of the crimes. ${ }^{70}$

In 1988 the Royal Ulster Constabulary pressed for compulsory DNA printing in some areas for use against Irish Republican Army ("I.R.A.") terrorists. ${ }^{71}$ Presumably, blood or hair left by a terrorist at the scene of a crime might be subjected to DNA printing, and the resulting print compared to those on file. In June 1988, the British government announced that the police in Northern Ireland could carry out compulsory DNA tests of suspected I.R.A. guerrillas. ${ }^{72}$

DNA printing is foreseeably vulnerable to abuse in both the public and private sectors of American society. The following subsections discuss a variety of potentially objectionable employments of the technology.

underway ultimately could make it possible to diagnose all of them from examination of the genome. Coles, The Pros and Cons of Freedom of Access to Human Genome Data, 333 NATURE 692 (1988); see also H. BUTZEL, GeNetics IN THE COURTS 722-25 (1987).

68. For a British perspective on these issues, see White \& Greenwood, supra note 59, at 155.

69. Governments currently collect fingerprints from millions of citizens in settings ranging from military induction, to campaigns against child kidnapping, to applications for driver's licenses. Similarly, authorities could turn to the collection of DNA prints (an identification method which is not limited to situations when a fingerprint impression is available), not merely from suspected or convicted criminals, but from the general population.

70. White \& Greenwood, supra note 59, at 149.

71. Id. at 148 n. 10 .

72. Britain Announces Genetic Tests for Guerrilla Suspects, Reuters, June 16, 1988 (AM cycle) (available on NEXIS). Civil libertarians in Ulster have denounced this measure. $N$. Ireland Civil Rights Body Attacks Genetic Fingerprint Plan, Reuters, Oct. 25, 1988 (AM cycle) (available on NEXIS). 


\section{Abuse by Governments}

Law enforcement agencies intend to create databases for storing the DNA prints of criminal offenders. In New York City, the Chief Medical Examiner has announced plans to begin routine DNA printing in "virtually all homicide investigations" beginning sometime in $1989 . .^{73}$ In California, the attorney general's office expects to have a statewide, computerized DNA database on line by the early 1990 's. ${ }^{74}$ The first entries will come from the blood and saliva samples of convicted sex offenders, which the state is now collecting for this purpose. ${ }^{75}$

California's Attorney General has noted, however, that DNA print databases could create a threat to privacy:

It is one thing to have fingerprints and criminal histories easily accessible to tens of thousands of peace officers. It is quite another to have information on-line that can mark you as a carrier of A.I.D.S.; or prove that you are not genetically related to either of your parents. Which of us would like to know that we are genetically predisposed to [a disease]? And which of us would be willing to have such information easily available to others?

[Although] we envision no such intrusive databank ... in this era of interlocking databases... [troubling issues will arise].

Some of the most predictable [issues] involve the temptation to engage in genetic fishing expeditions. For example, researchers now postulate that certain types of chromosomal deficiencies may incline people toward violent crimes. If D.N.A. analysis becomes commonplace, there will surely come a day when a desperate detective tries to run a search for every person with that deficiency in the vicinity of a series of unsolved murders. ${ }^{76}$

Are courts and legislatures compelled to protect citizens from the abuses of which the California Attorney General warned? Answering this question requires weighing competing interests: the individual's interests in privacy and the public interest in identifying criminal suspects.

Consider a hypothetical situation involving a detective who reviews individual DNA records in search of a serial criminal. The police have been baffled by a series of rapes. Technicians analyze semen recovered during the investigations to create a DNA profile, which reveals that the same man is responsible in each case, and that the man is genetically

73. City Plans DNA Tests in Murder Cases, Newsday, Nov. 25, 1988, at 9.

74. Barinaga, DNA Fingerprinting Database to Finger Criminals, 331 NATURE 203 (1988).

75. Id. Colorado also collects sex offenders' tissue samples for DNA printing. A similar system is planned for King County (metropolitan Seattle), Washington. Gest, Convicted By Their Own Genes, U.S. NEws \& WORLD REP., Oct. 31, 1988, at 70.

76. Address by John Van de Kamp, Attorney General of California, California Criminalistics Institute Seminar on D.N.A. Identification 3-4 (Jan. 7, 1988) (text on file with author). 
predisposed to a certain disease or has a particular congenital condition. Theorizing that the culprit may have sought treatment for his medical problen, the police visit doctors' offices, hospitals and clinics in the area. They request to inspect blood samples taken from men with this disorder, or DNA prints made for such nien in the course of treatment. At this point the public and private interests conflict.

Law enforcement officers may note that just as they enjoy ready access to tens of millions of fingerprint sets (originally taken from subjects for a variety of reasons which may not even have suggested law enforcement, such as induction to the armed forces) they should be able to obtain DNA prints (or DNA-bearing sample matter) from any source that collects them. Others, however, may argue that some special quality about DNA - the fact that it allows the analyst to look into the umique "blueprint" of each individual's body-is reason to prevent pohice use of citizens' DNA primts for the purpose of investigation by comparison.

These constitutional issues should be balanced. Rather than building a wall between the police and personal DNA information until after an arrest, society should create a middle path. To grant a measure of protection to individual privacy, the "genetic fishing expedition" imagined in the above hypothetical should be impermissible. However, in developing a case against a known suspect, at some point prior to arrest the police should be able to review his DNA prints. Procedures like those currently used for obtaining wire surveillance authorization (i.e., requiring a court order, granted on a showing of good cause) should be adopted. Such limited "genetic target shooting" probably would be acceptable to most people.

Government imsuse of DNA technology may extend beyond law enforcement agencies. For example, "school systems 1might require mandatory genetic screening of students to track developmental disabilities at the genetic level."77 Similarly, the government could attempt to link a particular genetic structure to a predisposition to criminality, screen youthful populations for identification of such a structure, and undertake "special treatment" for its carriers.

\section{Abuses by the Private Sector}

DNA printing also is vuhrerable to abuse by private parties. Although private use of DNA print technology falls outside the scope of this Comment, examples of the potential for private discrimination permitted by this technology underscore the need for protective regulation in this regard.

77. Matlack, Figuring the Cost of Genetic Research, 20 NAT'L J. 1143, 1144 (1988) (quoting Jeremy Rifkin). 
The most likely private misuse of DNA printing would coine froin employers and insurers. ${ }^{78}$ An employer might, for instance, screen out job apphicants with a genetic predisposition to chronic ailments that might cause time off the job or disability claims. Likewise, insurers would predictably be interested in a test that could reveal a congenital predisposition to certain diseases or the potential to develop AIDS. Moreover, since DNA may be obtained and printed without an individual's awareness or consent, the potential for abuse by private citizens is disturbing. Because DNA printing conclusively establishes paternity, for example, the technology could even be employed in family disputes for blackmail or intimidation.

Therefore, DNA print technology presents four major areas of concern: (1) the procedures currently lack validation by impartial scientists, (2) no mandatory uniform quality assurance standards exist to ensure consistency and reliability of test results, (3) procedural unfairness may result if hitigants do not receive equal access to the techmique and the test results, and (4) potential abuses of the technology may threaten individual privacy. While these concerns are significant, none are likely to be addressed if the acceptance of DNA printing is left solely to the courts. Because judges are limited to assessing the adinissibility of DNA printing as evidence, they are constrained, at least until the issues reach thein in a justiciable form, from examining the broader concerns of crime lab performance, procedural fairness, and individual privacy. Further, courts typically apply judicial admissibility tests with insufficient attention to the need for independent validation of novel scientific evidence. The following Part describes these judicial adınissibility standards.

III

The Laws of Novel Scientific Evidence: DNA Printing AND THe Courts

Prosecutors, and to a lesser extent defendants, now present DNA print evidence in court. Courts respond by applying the current standards for the admission of novel scientific evidence. This Part argues that these judicial standards inadequately address the problems of impartial validation, quality assurance, fairness, and privacy. This Part begins

78. Recently, a staff attorney at the American Civil Liberties Union's Project on Privacy and Technology noted with concern that insurers and employers could use large banks of DNA prints to determine a prospective insured or employed person's predisposition to a disease. "Our concerns are there are [sic] no regulations on the collection, storage, and use of the DNA. Therc has not been a very thoughtful public dialogue on the way we want to use the DNA print and the limits we want to put on its use." Stein, Genetic Fingerprinting Changes the Crime Game, L.A. Times, May 29, 1988, Pt. II, at 5, col.1 (bulldog ed.) (quoting Janlori Goldman of the ACLU). 
by describing the pertinent admissibility tests, and concludes by discussing several recent American cases that have addressed the admissibility of forensic DNA printing.

\section{A. The Admissibility Standards}

The standard used to admit novel scientific evidence varies among U.S. jurisdictions: some require proof of general acceptance of the test in its appropriate field or fields, and others admit, subject to certain protections for the opposing party, any relevant evidence and expert testimony that could assist the fact finder. Both standards seek to prevent the premature appearance of unreliable scientific evidence at trials and, at least in theory, both require validation of the forensic applications of a test before its results are admissible at trial. Courts, however, sometimes misapply these standards and admit scientific techniques that have not been validated by impartial experts, but have unobjectionable nonforensic applications, and the strong support of scientists interested in the technique's adoption.

\section{General Acceptance: the Frye Doctrine}

The Frye ${ }^{79}$ doctrine requires proof of general acceptance of the proffered type of evidence in the relevant scientific field or fields:

Just when a scientific principle or discovery crosses the line between the experimental and demonstrable stages is difficult to define. Somewhere in this twilight zone the evidential force of the principle must be recognized, and while courts will go a long way in admitting expert testimony deduced from a well-recognized scientific principle or discovery, the thing from which the deduction is made must be sufficiently established to have gained general acceptance in the particular field in which it belongs. ${ }^{80}$

The Frye doctrine prevails as the standard for admitting novel scientific evidence; ${ }^{81}$ it reigned for decades without strong challenge or meticulous examination. ${ }^{82}$ The doctrine may have received widespread acceptance because its use was confined to limited types of evidence, mostly polygraph evidence, and because courts in earlier decades did not face the varied and increasingly sophisticated types of scientific evidence

79. Frye v. United States, 293 F. 1013 (D.C. Cir. 1923) (barring results of a test by an early version of the "lie detector").

80. Id. at 1014. The court cited no authorities or precedents in its two-page opinion.

81. Giannelli, Frye v. United States, Background Paper Prepared for the National Conference of Lawyers and Scientists, 99 F.R.D. 189, 198 (1983).

82. MCCORMICK ON EvideNCE (3d ed. 1984 \& Supp. 1987) $§ 203$, at 606. 
common since the 1960 's. ${ }^{83}$ In recent years, however, courts and commentators have frequently criticized, often modified, and occasionally abandoned the doctrine. ${ }^{84}$ Even so, it remains the majority test and DNA printing will face some version of it in most jurisdictions.

\section{a. Frye's Analytical Guideposts}

The Frye decision gave no guidance for future application of the rule it pronounced: Subsequent case law provides the only guideposts to the meaning of "general acceptance." The Frye doctrine only asks whether a techmique generally has been accepted by experts in the relevant field or fields. To make this determination, a court must decide what level of scientific approval constitutes "general acceptance." 85

The level of approval that constitutes "general acceptance" is incapable of exact definition. In United States v. Zeiger, ${ }^{86}$ the court vaguely described the requisite level as "common to many, or the greatest number; widespread; prevalent; extensive though not universal." 87 Another court noted that evidence should not be admitted based on general acceptance among those who are unfamiliar with the scientific method. Rather, the measurement of a technique's acceptance should be whether it has been "generally accepted by those who would be expected to be familiar with its use." 88

Courts differ regarding the qualifications of expert witnesses. One court preferred witnesses who are qualified to represent the consensus of the scientific community. ${ }^{89}$ Courts may also attempt to secure testimony from qualified expert witnesses who oppose admission of the evidence based on the unreliability of the scientific method.

The California Supreme Court followed both policies in People v.

83. McCormick, Scientific Evidence: Defining a New Approach to Admissibility, 67 IowA L. REV. 879, 884-85 (1982).

84. See, e.g., MCCORMICK ON EvIDENCE, supra note 82, at 606-09. The same treatise notes the "difficult problems" posed by the Frye doctrine: "defining how 'general' the general acceptance must be, of discerning exactly what it is that must be accepted, and of determining the "particular field' to which the scientific evidence belongs and in which it must be accepted." Id. at 608 .

85. People v. Williams, 164 Cal. App. 2d Supp. 858, 331 P.2d 251 (1958) (determining whether Nalline pupil test for detection of narcotics was "generally accepted").

Courts also must decide to which scientific field or fields the technique belongs. For example, the Frye court suggested that experts in the fields of physiology and psychology could testify to the acceptance by their peers of the challenged lie detection method. Frye v. United States, 293 F. 1013, 1014 (D.C. Cir. 1923).

86. 350 F.Supp. 685 (D.D.C.), rev'd on other grounds, 475 F.2d 1280 (D.C. Cir. 1972).

87. 350 F.Supp. at 688 (quoting Platt v. Craig, 66 Ohio St. 75, 63 N.E. 594 (1902)).

88. People v. Williams, 164 Cal. App. 2d Supp. 858, 862, 331 P.2d 251, 254 (1958).

89. Commonwealth v. Lykus, 367 Mass. 191, 204 n.6, 327 N.E.2d 671, 678 n.6 (1975) (court gives more weight to the opinions of those with "direct and empirical experience in the field"); see also Giannelli, supra note 26, at 1215-16 (noting that the Pennsylvania Supreme Court, in Commonwealth v. Topa, $471 \mathrm{~Pa}$. 223, 232, 369 A.2d 1277, 1282 (1977), imposed a corroboration rule that required two experts to validate the procedure). 
Kelly. ${ }^{90}$ In Kelly a witness whose qualifications were "those of $a$ technician and a law enforcement officer, not a scientist" ${ }^{\prime 91}$ offered the only testimony on the proffered evidentiary technique. The court indicated that "[I]deally, resolution of the general acceptance issue would require consideration of the views of a typical cross-section of the scientific community, including representatives, if there are such, of those who oppose or question the new technique."92 Opposing witnesses could be appointed by the court, if necessary, to secure a balanced representation. ${ }^{93}$ The Kelly court warned that a strong advocate of a technique could be too closely identified with its endorsement to assess, fairly and impartially, scientific views on its reliabihity. ${ }^{94}$ Without additional impartial testimony about general acceptance, the trial court only could receive the witness' opimion "on faith." 95

In addition to expert testimony, courts have used scientific or legal publications, and even prior judicial opinions, to determine the admissibility of scientific evidence. For example, a Maryland appellate court im Cobey v. State ${ }^{96}$ conducted a broad review before rejecting Chromosome Variant Analysis. ${ }^{97}$ Cobey emphasized that, in addition to hearing competing testimony in ruling on "general acceptance," the court should go beyond the record to find materials that will assist it in making the decision. ${ }^{98}$

90. 17 Cal. 3d 24, 549 P.2d 1240, 130 Cal. Rptr. 144 (1976). Kelly, together with Frye, comprises the current standard for scientific evidence in California, often referred to as the KellyFrye rule. People v. Morris, 199 Cal. App. 3d 377, 386, 249 Cal. Rptr. 52,57 (1988).

91. Kelly, $17 \mathrm{Cal}$. 3d at 39, 549 P.2d at 1250, $130 \mathrm{Cal}$. Rptr. at 154 (emphasis in original).

92. Id. at 37,549 P.2d at 1248,130 Cal. Rptr. at 152 .

93. Id. at 37, 549 P.2d at 1249, 130 Cal. Rptr. at 153 (citing Comment, The Voiceprint Dilemma: Should Voices be Seen and not Heard?, 35 MD. L. REv. 267, 293 (1975) (suggesting that the court seek out opposing witnesses)).

94. Kelly, 17 Cal. 3d at 38, 549 P.2d at 1249, 130 Cal. Rptr. at 153; see also People v. Young, 425 Mich. 470, 483, 391 N.W.2d 270, 275 (1986) (" $[\mathrm{A}]$ certain degree of 'interest' must be tolerated if scientists familiar with the theory and practice of a new technique are to testify at all'). But see People v. Reilly, 196 Cal. App. 3d 1127, 1139, 242 Cal. Rptr. 496, 504 (1987) (court looks for "the degree of self-interest that renders [an expert's] testimony flatly unacceptable").

95. Kelly, $17 \mathrm{Cal} .3 \mathrm{~d}$ at 38, 549 P.2d at 1249, $130 \mathrm{Cal}$. Rptr. at 153.

96. 73 Md. App. 233, 533 A.2d 944 (1987), cert. denied, 312 Md. 127, 538 A.2d 778 (1988).

97. Chromosome Variant Analysis attempts to establish paternity by comparing the chromosomes of the child, mother, and putative father. In Cobey, this analysis was performed upon a rape victim's aborted fetus in hopes of demonstrating that the alleged rapist was the "father." Id. at $236,533 \mathrm{~A} .2 \mathrm{~d}$ at 946.

98. Id. at $244,533 \mathrm{~A} .2 \mathrm{~d}$ at 950 . Courts deciding novel scientific evidence questions should look outside the record, simply as a fail-safe against the possibility that counsel and their trial experts may not have noticed, or alerted the court to, significant publications relevant to the scientific status of proffered evidence. See, e.g., People v. Brown, $40 \mathrm{Cal}$. 3d 512, 533, 709 P.2d 440, 450, $220 \mathrm{Cal}$. Rptr. 637, 647 (1985); People v. Shirley, 31 Cal. 3d 18, 56, 641 P.2d 775, 797-98, 181 Cal. Rptr. 243, 266, cert denied, 458 U.S. 1125 (1982). In this light, independent review of the general scientific literature may be seen as insurance against an incorrect opinion of the strength of the evidence and a resulting incorrect decision. 


\section{b. Likelihood of Premature Admission Under Frye}

Failure by courts to apply the Frye doctrine vigorously will lead to the premature admission of DNA printing. The difficulty lies in the malleability of the definition of "general acceptance" and the Frye doctrine itself. The "general acceptance" standard is drawn so vaguely that forensic DNA printing can survive a Frye hearing, ${ }^{99}$ even though little published vahidating material exists and the laboratories define the quality assurance standards autonomously. Unfortunately the alternative to the Frye doctrine provides no better protection against the premature admission of novel scientific evidence.

\section{The Relevancy Test}

The standard requiring simply relevancy and expert testimony is the major alternative to the Frye doctrine. Jurisdictions following a relevancy standard may admit "[a]ny relevant conclusions supported by a qualified expert witness ... unless there are distinct reasons for exclusion. These reasons are the familiar ones of prejudicing or misleading the jury or consuming undue amounts of time." 100 Since the introduction of the Federal Rules of Evidence and many related state evidentiary rules, the relevancy standard may have replaced Frye due to the Federal Rules' possible implicit rejection of the latter. For the time being, the Federal Rules, and state codes based on the Rules, coexist with the Frye doctrine in several jurisdictions. ${ }^{101}$

Increased use of the relevancy standard for judging the admissibility of novel scientific evidence paralleled the increased criticism and rejection of the Frye doctrine. The relevancy standard now operates in a significant minority of states, as well as in at least two federal circuits. ${ }^{102}$

99. See infra notes 126-54 and accompanying text.

100. MCCORMICK ON EVIDENCE, supra note 82, § 203, at 608 (footnote omitted).

101. Federal Rules 401,402 , and 702 seem to indicate that any relevant scientific evidence or testimony is admissible if it will assist the trier of fact and is not prejudicial, misleading, or overly time-consuming. However, neither the Federal Rules, nor their official commentaries, mention thc Frye doctrine, leaving it unsettled whether the general acceptance standard had been replaced. Courts and legal scholars conflict on this issue. McCormick, supra note 83, at 886-88.

This Comment will not discuss admissibility of evidence under the Federal Rules as a separate matter. In 1988, twenty-eight states, Puerto Rico, and Guam had adopted evidentiary rules similar to the Federal Rules. 13A U.L.A. 1 (1986 \& Supp. 1989).

102. See United States v. Downing, 753 F.2d 1224, 1237 (3d Cir. 1985); United States v. Williams, 583 F.2d 1194, 1198 (2d Cir. 1978), cert. denied, 439 U.S. 1117 (1979); Whalen v. State, 434 A.2d 1346, 1354 (Del. 1980), cert. denied, 455 U.S. 910 (1982); Kruse v. State, 483 So. 2d 1383, 1385 (Fla. Dist. Ct. App. 1986); State v. Hall, 297 N.W.2d 80, 84-85 (lowa 1980), cert. denied, 450 U.S. 927 (1981); State v. Catanese, 368 So. 2d 975, 980 (La. 1979); State v. Williams, 388 A.2d 500, 503-04 (Me. 1978); Barmeyer v. Montana Power Co., 202 Mont. 185, 193-94, 657 P.2d 594, 598 (1983), overruled on other grounds, Martel v. Montana Power Co., 752 P.2d 140 (Mont. 1988); State v. Williams, 4 Ohio St. 3d 53, 56-58, 446 N.E.2d 444, 447-48 (1983); State v. Kersting, 50 Or. App. 461, 470, 623 P.2d 1095, 1101 (1981), affd, 292 Or. 350, 354-55, 638 P.2d 1145, 1147 (1982); 
Advocates of the relevancy standard argue that it elimmates the need for a complex Frye-style analysis and allows fact finders to hear useful evidence without a time-lapse for the spread of general acceptance in a scientific peer group. ${ }^{103}$ For precisely these reasons however, the relevancy standard is even more likely than the Frye standard to lead to the premature admission of novel scientific evidence.

\section{a. "Balancing" the Issues Under a Relevancy Standard}

The decision to admit or bar novel scientific evidence in a jurisdiction using the relevancy test depends upon the balance between (1) the reliability and informative value of the evidence and (2) the possible unfairness to the opposing party. As the Third Circuit prescribed in United States v. Downing, ${ }^{104}$ the trial court's inquiry should focus on:

(1) the soundness and reliability of tle process or technique used in generating the evidence, (2) the possibility that admitting the evidence would overwhelin, confuse, or mislead the jury, and (3) the proffered connection between the scientific research or test result to be presented, and particular disputed factual issues in the case. ${ }^{105}$

After surveying leading relevancy cases, one cominentator recommended that courts consider the novel technique's potential error rate, the existence of safeguards and standards of practice for good performance, the nature of the inference adduced, and the probative significance of the proffered evidence in the particular circumstances. ${ }^{106}$ These factors indicate that a court applying the relevancy standard should consider the subject procedure's pedigree and performance record in determining its reliability. ${ }^{107}$ Courts should scrutinize particularly closely a scientific method's quality control measures. ${ }^{108}$ Unfortunately, courts have laxly conducted inquiries into these issues. ${ }^{109}$

\section{b. Potential to Mislead a Jury}

The Downing court indicated that the reliabihity of the evidence

Phillios ex rel. Utah State Dep't of Social Servs. v. Jackson, 615 P.2d 1228, 1234-35 (Utah 1980); Watson v. State, 64 Wis. 2d 264, 275, 219 N.W.2d 398, 403 (1974); Cullin v. State, 565 P.2d 445, 457-58 (Wyo. 1977).

103. Giannelli, supra note 26 , at 1223 (noting that the Frye doctrine's lag period may operate to deprive courts of reliable evidence).

104. 753 F.2d 1224 (3d Cir. 1985).

105. Id. at 1237 .

106. McCormick, supra note 83 , at $911-12$.

107. Downing, 753 F.2d at 1238-39 (citing commentators and cases which emphasize the "novelty" of the technique, the existence of specialized literature, the qualifications and stature of expert witnesses, and nonjudicial uses of the technique as factors to consider).

108. See, e.g., United States v. Williams, 583 F.2d 1194, 1198-99 (2d Cir. 1978), cert. denied, 439 U.S. 1117 (1979) ("existence and maintenance of standards," "care and concern" of application, and presence of "fail-safe characteristics" are all indicia of reliability).

109. See Giannelli, supra note 26 , at $1235-39$. 
must be balanced against the potential of the evidence to mislead, confuse, or overwhelm the jury. Lay jurors may be overly impressed by scientific tests, laboratory results, and witnesses with strings of academic credentials. ${ }^{110}$ As a result, they may feel compelled to accept a highly scientific, novel test such as DNA printing without question. This danger increases with the relative incomprehensibility of the actual procedure to a lay person.

Some will note that courts cannot refuse to admit scientific evidence just because jurors are not always intelligent enough to understand it. However, the fact that juries are made up, in part, of those who cannot understand complex scientific concepts, strengthens the arguments that this Comment is making: that prior to admission of a new evidentiary method, experts should be called on to "fool-proof" it, by ascertaining its true capabilities and hedging it about with guarantees of quality performance.

State v. Hall ${ }^{111}$ confronted the problem of undue influence. In Hall, the Iowa Supreme Court ruled that "blood splatter analysis" was admissible at least partly because the method of analysis was relatively simple for a lay juror to understand and evaluate. To the court, blood splatter analysis was more akin to physical comparisons of handwriting samples and ballistics markings than to laboratory techniques. ${ }^{12}$ Therefore, a juror of average intelligence could readily comprehend the method and independently evaluate the expert's opinion. Because complex scientific evidence is difficult for jurors to evaluate, one commentator has suggested that any technique that is too complex for the lay juror to understand in more than general terms should require a stronger showing of soundness and reliability. ${ }^{113}$ DNA printing falls into this category of scientific evidence.

DNA printing, a laboratory technique which utilizes complex molecular biology concepts, is not the type of physical comparison evidence that the average juror can readily comprehend in detail. ${ }^{114}$ Moreover, it has received substantial, and in many cases exaggerated, media

110. But see Imwinkelried, The Standard for Admitting Scientific Evidence: A Critique from the Perspective of Juror Psychology, 100 M1L. L. REV. 99, 113 (1983) (challenging the assumption that jurors cannot competently evaluate scientific evidence).

111. 297 N.W.2d 80 (Iowa 1980), cert. denied, 450 U.S. 927 (1981).

112. Id. at 86. "Blood splatter analysis" involves the examination of blood patterns on clothing or elsewhere in light of studies of blood flight characteristics, to determine, for example, whether a defendant stabbed a victim and was splattered by spurting blood, or only picked up the body. This was the situation in Hall. See also State v. Philbrick, 436 A.2d 844, 861 (Me. 1981) (rejecting testimony of a detective who had attended training course at a "blood-splatter school").

113. MCCORMICK ON EVIDENCE, supra note 82, § 203, at 609.

114. Cf. Ex parte Dolvin, 391 So. 2d 677, 679 (Ala. 1980) (examination of skeletal remains); People v. Marx, 54 Cal. App. 3d 100, 101, 126 Cal. Rptr. 350, 356 (1975) (dental impressions in skin). 
coverage. ${ }^{115}$ As such, DNA print evidence is likely to make a very strong impression on the jury and may unfairly prejudice jurors' judgment of the defendant. Yet DNA printing has been accepted by an appeals court under the relevancy standard in at least one jurisdiction. ${ }^{116}$

This section has discussed the "general acceptance" (Frye) and "relevancy" standards for the admission of novel scientific evidence. It has argued that current application of the standards supplies insufficiently stringent barriers and allows the premature admission of DNA print evidence. ${ }^{117}$ The next section will describe actual cases in which DNA printing was used as evidence. Analysis of these cases demonstrates that courts have taken advantage of the vague evidentiary tests by avoiding or ignoring problems of impartial validation, quality assurance, fairness, and privacy.

\section{B. The DNA Cases}

The use of DNA printing has increased steadily since 1987 when it became readily available to criminal mvestigators in the United States. With more or less alacrity, ${ }^{118}$ prosecutors in several states have introduced DNA prints as evidence in a handful of trials, though only one

115. See, e.g., Begley, Leaving Holmes in the Dust-Gene Prints Unravel Crime and Paternity Puzzles, NewswEeK, Oct. 26, 1987, at 81 ("DNA fingerprints will someday send other crime-lab tests the way of Sherlock Holmes's magnifying glass"). From the beginning, reporters on the lookout for exciting science feature stories have been enamored with forensic DNA printing. See, e.g., Hicks, One in a Trillion: Sheriff Wants 1st DNA Lab in State, L.A. Times, Nov. 14, 1988, Pt. II, at 1, col.1 (quoting a county chief criminalist as saying: "DNA testing is so specific, we can say that only one in a billion, even one in a trillion [males could have a particular blood type])." The latter figure, reflecting the most optimistic marketing estimate of Cellmark Diagnostics (and a number many times greater than the number of humans who have ever lived on earth), is not only untestable, but also was presented with no qualifying statements to reflect the actual facts and probabilities of forensic testing. It would have been seen by millions of newspaper readers in southern California and elsewhere. "[A]n exaggerated public opinion of the accuracy of a particular technique [may makel its use prejudicial or likely to mislead the jury." United States v. Baller, 519 F.2d 463, 466 (4th Cir.), cert. denied, 423 U.S. 1019 (1975).

116. See infra notes $126-43$ and accompanying text.

117. Premature admissions have occurred under both evidentiary tests. One notorious example is the "paraffin test" for gunpowder residue on the skin, performed by pouring warm liquid paraffin wax over the suspect's hand, letting it solidify, and then applying to the wax mold a reagent which supposedly reacted with gunpowder residues, showing that the suspect recently fired a gun. From the 1930's to the 1960's, the paraffin test was used widely in the United States and approved by many courts. In the 1960's, the first comprehensive scientific study of the paraffin test showed that it was actually very nonspecific; the reagent would show a reaction when combined with, for example, tobacco ash, nail polish, or urine. Giannelli, supra note 26, at 1224-27.

More recently, voice spectrography or "voiceprinting" was admitted and upheld in a number of courts around the country in the 1970's. Many, though not all, of the courts admitted the testimony of experts whose professional careers were entwined with the progress of voiceprinting. After a few years, a National Academy of Sciences study of voiceprinting disputed many of the proponents' claims, and voiceprinting declined. Id. at 1225 n.217.

118. In California in 1988, for example, the state Attorney General ordered state criminal investigators not to employ DNA printing until the technique had been studied more. Address by 
appellate court has ruled on its admissibility to date. ${ }^{119}$ Relatively few forensic DNA printings have been performed to date, but sources indicate that the number of tests for forensic purposes could rise dramatically in the future. ${ }^{120}$

\section{Introduction of Forensic DNA Printing}

Following an auspicious debut in Great Britain, forensic DNA printing quickly jumped the Atlantic. By early 1987, the Lifecodes Corporation, which had already been offering the service for paternity testing, began to inarket its version of the test as a tool for criminal investigators. ${ }^{121}$ Later that same year, Cellinark Diagnostics, the American subsidiary of Britain's Imperial Chemicals Industries, began offering the Jeffreys method. ${ }^{122}$ The Cetus Corporation was the third company to offer the test.

Prosecutors eagerly sought to employ the new technique in criminal trials. A notable initial use in Washington led to a confession and subsequent conviction. ${ }^{123}$ Prosecutors in Florida in $1987^{124}$ and New York in $1988^{125}$ also sought to introduce the test results into trial. The leading Florida and New York cases are the best-docuinented and most controversial uses of forensic DNA printing in the United States so far.

\section{a. Florida: The Andrews Case}

In November, 1987, Tommie Lee Andrews becaine the first person in the United States to be convicted on the basis of DNA printing while maintaining his innocence throughout his trials. ${ }^{126}$ His case also produced the first appellate decision on the admissibility of DNA prints. ${ }^{127}$

Andrews was accused of burglary and rape. The prosecution offered no witnesses to counter Andrews' alibi except the victim, who could not

John Van de Kamp, supra note 76, at 8. Early in 1989, the Attorney General authorized use of the technique in selected upcoming murder trials. Van de Kamp OKs 'Genetic Fingerprint' Use in Trials, L.A. Times, Jan. 25, 1989, Pt. I, at 3, col. 4.

119. Andrews v. State, 533 So. 2d 841 (Fla. Dist. Ct. App. 1988).

120. See L.A. Times, Jan. 7, 1988, Pt. I, at 3, col. 2 (noting that the technique's unique capabilities will ensure its widespread use).

121. NAT'L L.J., Jan. 18, 1988, at 42, col. 3.

122. Begley, supra note 115 .

123. Comment, supra note 2, at 904 (discussing use of DNA printing in case of defendant charged with rape).

124. State v. Andrews, No. 87-1659, (Fla. Cir. Ct. (Orange County) Nov. 1987), affd, Andrews v. State, 533 So. 2d 841 (Fla. Dist. Ct. App. 1988).

125. People v. Wesley, 140 Misc. 2d 306, 533 N.Y.S.2d 643 (1988).

126. Andrews, No. 87-1659 (Fla. Cir. Ct. (Orange County) Nov. 1987); see also NAT'L L.J., supra note 121, at 42, col. 1 (discussing the Andrews case).

127. Andrews, 533 So. 2d 841, 843 (Fla. Dist. Ct. App. 1988) (stating that the court "found no other appellate decision addressing the admissibility of DNA identification evidence in criminal cases"). 
identify Andrews' face or voice. The results of traditional blood and semen typing were insufficient to link Andrews to the crime. ${ }^{128}$ The prosecution, however, arranged for the Lifecodes Corporation to test the semen recovered from the victim. Lifecodes concluded that the rapist's DNA matched that of Andrews. ${ }^{129}$ Andrews was convicted and sentenced to twenty-two years in prison. ${ }^{130}$

At trial, the prosecution presented three expert witnesses who testified in support of the test: two were scientists from Lifecodes, and one was a professor from the Massachusetts Institute of Technology. They testified that DNA printing is based on generally accepted scientific principles, that the Lifecodes method had been examined and proven accurate and reliable, and that the laboratory procedure and quality control when performing the test had been irreproachable. ${ }^{131}$ On the basis of this expert testimony, the prosecution argued that the claimed identification of Andrews as the rapist should be admitted as evidence. ${ }^{132}$

The defendant was unable to produce expert witnesses of his own to counter this testimony. His attorney contacted scientists at a number of universities, but none were willing to testify on his behalf. ${ }^{133}$ After learning that the FBI had decided to forestall the use of DNA printing pending further examination of its scientific validation, Andrews' attorney attempted to obtain a witness from that agency, but the Bureau denied the request. ${ }^{134}$

Andrews questioned the reliability of the DNA teclinique and attacked the quality control standards of the Lifecodes laboratory. Testimony indicated that malfunctioning test equipment, improperly prepared reagents or gels, and variations in voltage might affect the test outcome. ${ }^{135}$ Defense counsel argued that the gel used at Lifecodes came from an outside supplier, that one of the Lifecodes witnesses was unsure of that supplier's quality standards, and that the inspection of gel shipments received by Lifecodes was limited to cliecking it "to inake sure it works the way that the old lot of gel works." 136 This testimony, offered

128. Tests showed only that the defendant and the rapist were among about two-thirds of the male population with the same characteristics. Id.

129. A Lifecodes manager, Dr. Michael Baird, testified that the chance that the DNA strands found in Andrews' blood could have been matched by someone else's was 1 in 839,914,540, and that Andrews' DNA print matched that of the DNA recovered from the semen. Id.

130. NAT'L L.J., supra note 121 , at 42 , col. 1 ; see also L.A. Times, supra note 120 , at 28 , col. 4 (discussing the use of DNA prints to obtain such a conviction).

131. Initial Brief of Appeilant at 6-8, Andrews v. State, 533 So. 2d 841 (1988) (no. 87-2166).

132. See generally Answer Brief of Appellee at 21-37, Andrews v. State, 533 So. 2d 841 (1988) (no. 87-2166) (arguing that the trial court properly admitted DNA print results into evidence).

133. Telephone interview with Mr. James Valorino, of the law offices of Harold Uhrig, Orlando, Florida (Mar. 28, 1988).

134. Id.

135. See Initial Brief of Appellant, supra note 131, at 11.

136. Id. at 12 . 
at the evidentiary hearing, did not lead the trial court to exclude the DNA print evidence.

On appeal, Andrews attacked Lifecodes' quality control system. ${ }^{137}$ He argued that defects in the administration of the DNA test may have affected its results, and the court therefore should not have admitted the test results in this particular case. ${ }^{138}$ In response to this narrow appeal, however, the state sought a broad pronouncement of approval for DNA print technology. The state's reply brief primarily focused on arguments that Andrews had not raised on appeal. ${ }^{139}$

A Florida appeals court affirined Andrews' convictions. ${ }^{140}$ The decision was predictable, since Andrews apparently waived any broad challenge to the forensic technique, and because Florida evidence law traditionally receives novel scientific evidence quite hospitably. ${ }^{141}$ In addition the court concluded that the trial court had not, on the evidence for reliability presented, abused its discretion in admitting the DNA print evidence. ${ }^{142}$ The court explicitly adopted the relevancy standard, while noting that the state supreme court had not spoken definitively on the matter. ${ }^{143}$

After Andrews, DNA printing is admissible in Florida cases. Although Andrews raised the issue of quality control, the court did not bar the evidence on that basis. Considerations of procedural fairness and individual privacy were not before the court in this appeal. As a result, DNA printing is now presumably admissible in Florida, but without uniform quality standards, procedural protections, or privacy safeguards.

\section{b. New York: Wesley-Bailey and Lopez}

As in Florida, the New York courts are receptive to DNA printing

137. See id. at $10-14$.

138. Id. at 10 .

139. For example, the state provided the professional biographies of its expert witnesses, although their qualifications had not been challenged. Answer Brief of Appellee, supra note 132, at 1-3. The state also described at length both the general acceptance of electrophoretic methods of blood typing and the recent research in molecular biology. Id. at 4-7. Almost in passing, the state scorned Andrews' suggestion that some quality control fiaw at Lifecodes could have affected his particular test. Id. at 9-10, 17-18.

140. Andrews v. State, 533 So. 2d 841 (Fla. Dist. Ct. App. 1988).

141. See, e.g., Coppolino v. State, 223 So. 2 d 68 (Fla. Dist. Ct. App. 1968), cert. denied, 399 U.S. 427 (1970). In this celebrated prosecution of a physician for the murder of his wife, the trial court accepted a forensic test indicating the presence of a particular chemical in the victim's body, even though the test had only been developed for use in that particular investigation. The denial of Dr. Coppolino's appeal represented the first significant departure from the Frye doctrine in an American court. See id. at 70-71 (discussing applicable law on admission of scientific evidence).

142. Andrews v. State, 533 So. 2d at 850 . The appeals court found no merit in Andrews' contention that Lifecodes' quality controls for the gel used in the laboratory might have been suspect. Id. at 849.

143. Andrews, 533 So. $2 \mathrm{~d}$ at $846-47$ \& n.6. 
as evidence in crimmal prosecutions. Last year, DNA printing survived a consolidated Frye evidentiary liearing in two unrelated criminal cases pending in the same New York county. ${ }^{144}$ DNA prints were also allowed as evidence in a separate New York serial rape case. The New York courts, like the Andrews court, apparently based their decisions on findings that DNA printing was considered valid by scientists and that the accuracy claims and quality control program of the testing laboratory were acceptable.

\section{The Wesley-Bailey Hearing}

In People v. Bailey, ${ }^{145}$ a rape victim became pregnant and liad the fetus aborted. The prosecution souglit to compare the DNA prints of the fetus and Bailey to determine wliether he had impregnated tlie victim. ${ }^{146}$ In People v. Wesley, ${ }^{147}$ the prosecution had successfully matched the DNA print of the victim's blood witl bloodstams found on the defendant's clothing and wanted to make a DNA print from the defendant's blood to confirm that the bloodstains were not his. ${ }^{148}$ In both cases, the court ruled the tests admissible at the Frye hearing. ${ }^{149}$

The statistical support for the accuracy claims of the Lifecodes technique and the quality assurance standards of the laboratory were at issue in the Frye hearing. The defense conceded that DNA printing was scientifically valid in theory, but called three expert witnesses to testify regarding quality control and population genetics. ${ }^{150} \mathrm{~A}$ genetic statistician testified that the Lifecodes statistical sampling was too small to justify the method's claimed discriminating powers. A doctor (wlo was also a blood bank director) criticized Lifecodes' quality control standards as inadequate to assure DNA test reliability. ${ }^{151} \mathrm{~A}$ doctor from the state department of public liealtl testified tliat her department had not yet developed quality control guidelines or hicensed DNA printing as a medical diagnostic technique. ${ }^{152}$

The court was persuaded, lowever, by the prosecution's experts, whiclı mcluded two prominent geneticists, a scientist from Lifecodes, and

144. People v. Wesley, 140 Misc. 2d 306, 533 N.Y.S.2d 643 (1988); see also Upstate Judge Orders Genetic Fingerprints, N.Y.L.J., July 27, 1988, at 1, col. 7 (discussing this opinion).

145. 140 Misc. 2d 306, 533 N.Y.S.2d 643 (1988).

146. Id. at 331,533 N.Y.S.2d at 659.

147. 140 Misc.2d 306, 533 N.Y.S.2d 643 (1988).

148. Id. at 331,533 N.Y.S.2d at 659 .

149. Id. at 332,533 N.Y.S.2d at 659 .

150. Id. at $317-18,329-30,533$ N.Y.S.2d at $650-51,657-58$. The opinion mentions only two defense expert witnesses. The defense counsel at the hearing informed the author of a third, a health department official. Telephone interview with Hon. Douglas P. Rutnik, Public Defender, Albany, New York (Oct. 24, 1988).

151. Id. at 318,533 N.Y.S.2d at 651.

152. Telephone interview with Hon. Douglas P. Rutnik, supra note 150. 
a biology professor from a nearby college. Based on their testimonies and on certain scientific articles, the court found that various relevant scientific fields had generally accepted DNA printing. ${ }^{153}$ The court also approved of the quality assurance practices in force at Lifecodes. ${ }^{154}$

\section{The Lopez Case}

In October 1988, New York prosecutors successfully used DNA printing in a criminal jury trial, People v. Lopez. ${ }^{155}$ Lopez was accused of multiple rapes. The prosecution sought to introduce DNA print evidence derived from semen recovered from one of the rape victims. The court admitted the evidence despite defense counsel's effort to cast doubt on the unreliability of the test. ${ }^{156}$

The DNA print evidence appeared crucial to the prosecution's case, since each of Lopez's alleged victims at first described her attacker as a black man, but later identified Lopez, who is not dark-skinned, as the rapist. ${ }^{157}$ Lopez pleaded not guilty to all charges and claimed mistaken identity as a defense. ${ }^{158}$

The jury convicted Lopez after nine hours of deliberation. According to one juror, although the entire jury had been inclined to convict, the DNA evidence was "... a sealer on the thing. You can't really argue with science." 159 Another stated that at least five jurors had trouble understanding the theory behind DNA and its applicability. ${ }^{160}$

\section{c. DNA Printing for the Defense-The Prosecutor's Dilemma}

In some states, prosecutors may oppose the use of forensic DNA printing by defendants. For exainple, in Illinois a defendant sought to exculpate himself by means of DNA testing, and met resistance from the state.

The issue of DNA printing arose over a ten-year-old cause célebre, the case of Gary Dotson. Dotson was convicted in 1979 for the rape of Cathleen Crowell Webb and sentenced to a long prison term. In 1985, Webb publicly recanted her story. The governor of Illinois commuted

153. Wesley, 140 Misc. $2 \mathrm{~d}$ at $317-31,533$ N.Y.S.2d at $650-59$.

154. Id.

155. See Man Convicted of Rape on DNA Evidence, N.Y. Times, Oct. 20, 1988, at B1, col. 2 (discussing jury verdict); see also Prosecutors Move to Give DNA Evidence in Rape, N.Y. Times, Sept. 30, 1988, at B3, col. 1 (describing prosecutor's attempts to introduce DNA prints as evidence).

156. See Man Convicted of Rape on DNA Evidence, supra note 155, at B1, col. 1.

157. Id. at B16, col. 1. The prosecution argued that Lopez's skin may have been darker in the summer when the crimes took place.

158. Id.

159. Id. at B16, col. 2 (emphasis added). Lopez, a habitual criminal with prior convictions for burglary and kidnapping, was not an appealing defendant under any circumstances.

160. Id. A 22-year-old dental hygienist juror explained the method to the five jurors' satisfaction. 
Dotson's sentence to time already served, but did not grant a pardon. Early in 1988, the governor's representative sent a semen stain collected at the time of the alleged rape to Dr. Jeffreys for DNA print analysis. Dr. Jeffreys performed the test, but found the semen to be "too degraded for analysis."161 Dotson, seeking a recommendation for pardon froin the state Prisoner Review Board, had the semen stain tested by the Cetus method, which requires far less material than the Jeffreys system. ${ }^{162} \mathrm{He}$ argued that the Cetus test "positively eliminated [him]" from suspicion. ${ }^{163}$ Moreover, according to the test, Webb's boyfriend at the time of the alleged rape was among the $5 \%$ of inales who could have produced the semen. ${ }^{164}$ In opposing Dotson's request for a pardon recommendation, ${ }^{165}$ the state contended that "[t] here have been insufficient validation studies showing this test ${ }^{166}$ is rehiable." 167 Moreover, the state's attorney contended that since DNA could not be used as evidence in Illinois courts, it should not be the basis for recommending the pardon. ${ }^{168}$

\section{Summary}

The previous review of cases considering the admissibility of forensic DNA printimg reveals a nascent pattern. Courts have been willing to admit the test results, basing this decision largely on the testimony of representatives of the commercial laboratories performing the tests and the results of in-house validation studies, supplemented by supportive testimony froin geneticists with little or no forensics background. In

161. Genetic Testing Fails to Prove a Rape Case, N.Y. Times, Apr. 8, 1988, at A4, col. 1.

162. See Dotson Cites Test, Seeks a Full Pardon, Chicago Tribune, Oct. 15, 1988, § 2, at 1, col. 1.

163. Id.

164. Id. See also Cetus Royalties, supra note 54 (discussing application of Cetus test to Dotson case semen sample).

165. The prosecutors from the office that convicted Dotson have vigorously contested Webb's recantation and Dotson's attempts to get a pardon. Frossard, When the Accuser Recants: People v. Dotson, 14 Litigation, No. 4, 11, at 11-12 (1988). In the same article, the author, chief of the Felony Trials Division of the Cook County (Illinois) State's Attorney's Office, wrote about recantations: "If you get a conviction ... you have a stake in it. If a meddling lawyer threatens to snatch your verdict away because some dubious character supposedly lied, your next move is obvious: Fight like a tiger. Charge right in and show that the recantation, not the testimony supporting your verdict, is false." Id. at 12 (emphasis in original).

166. Whether the state's attorney meant DNA printing in general, or the Cetus method in particular, is uncertain.

167. Dotson Cites Test, supra note 162.

168. Id. The Prisoner Review Board unanimously recommended a pardon. The state governor decided to withhold his decision until he could determine the scientific reliability of the Cetus test. Illinois Governor Withholds Decision in 1977 Rape Case, N.Y. Times, Oct. 25, 1988, at A20, col. 4. To date, there has apparently been no decision.

Illinois police investigators have recently used the Lifecodes test to identify a suspect in a string of rapes. According to a police detective, DNA printing had not yet been used as evidence in Illinois criminal cases, and therefore, this case had the potential to establish precedent. Wurth, Police Arrest Campus Rape Suspect, 19, Champaign (Ill.) News-Gazette, Jan. 22, 1989, at A-8, col. 2. 
addition, the absence of quality control regulation has not led to the evidence's exclusion.

Judges in the New York and Florida cases have based their decisions on the testimony of self-interested experts or witnesses with no forensic experience. ${ }^{169}$ Further, judicial approval of the Lifecodes test for use in New York or Florida trials is quite likely to bring financial or professional gains to the corporation or its personnel. ${ }^{170}$ The self-interest of witnesses, or their lack of direct experience, may not have been taken sufficiently into account by the courts in these cases, even though a different admissibility standard was used in each state. In New York, the trial court at least heard opposing expert testimony; in Florida there was none, and the court did not take the optional step of appointing any experts. ${ }^{171}$

Courts may hold that possible witness bias goes to the weight (or credibility), not the admissibility, of DNA printing. In so doing, the courts would follow the trend toward softened admission barriers, with the remaining inquiry into the weight to be granted the evidence. ${ }^{172}$ This situation strengthens the case for a legislative approach to adopting DNA printing - since courts are seemingly less likely than ever to give a new inethod tough scrutiny before admitting it.

This Part has described the admissibility tests for novel scientific

169. In Andrews v. State, 533 So. 2 d 841 (Fla. Dist. Ct. App. 1988), the prosecution's experts were two Lifecodes employees and a geneticist whose curriculum vitae revealed no forensic work. Similarly, in the Wesley-Bailey evidentiary hearing, the pro-admission expert witnesses were a Lifecodes employee, an associate biology professor, and two prominent research geneticists. There was no showing of forensic experience for any of the latter three "academic" witnesses.

170. The trial judge in Wesley-Bailey noted that Lifecodes' witness, Dr. Michael Baird, "is neither a stockholder nor the holder of any stock options" in the chemical eompany which now owns Lifecodes. People v. Wesley, 140 Misc. 2d 306, 323, 533 N.Y.S.2d 643, 654 (1988). The eourt incorrectly assumes that no other means of gaining financial rewards exist, ignoring raises and bonuses, or other incentives normally given to key employees in a profitable business. In addition, the court completely overlooked the professional prestige that could accrue to a relatively obscure scientist through the wider acceptance of the Lifecodes method.

171. Securing the services of experts to examine evidence, to advise counsel, and to rebut the prosecution's case is probably the single most critical factor in defending a case in which novel scientific evidence is introduced. Nevertheless, a surprising number of novel techniques have gained admissibility without the presentation of defense expert testimony. Incredibly, several courts have cited the absence of opposing experts to support their decision to admit [a novel technique], apparently inferring reliability from a laek of opposition. This inference is unwarranted.

Giannelli, supra note 26, at 1243 (footnotes omitted).

172. Professor Imwinkelried has described this trend:

[A particular admission of blood typing evidence] augurs the way in which the courts will probably deal with novel scientific evidence in the 1980's: if the reliability of the evidence is demonstrable, the courts will waste little time in ruling the evidence admissible; and the real debate over the evidence in this decade will be the resolution of the probative weight of the evidence.

Imwinkelried, $A$ New Era in the Evolution of Scientific Evidence-A Primer on Evaluating the Weight of Scientific Evidence, 23 WM. \& MARY L. REv. 261, 272 (1981); see also McCoRMICK ON EVIDENCE, supra note $82, \S 203$, at 609-10. 
evidence and reviewed the initial cases using DNA print evidence. ${ }^{173}$ The outcome of these cases demonstrates that courts applying traditional admissibility tests are likely to admit DNA evidence prematurely, with no resolution of the probleins of quality assurance, fairness, or privacy. Part IV will outline an alternative to address all of these concerns: a unitary legislative approach.

\section{IV}

\section{A Model for Legislative Management of The INTRODUCTION OF DNA PRINTING}

\section{A. The Need for Legislative Action}

There are limitations inherent in the admissibility hearing settimg that prevent courts from addressing the concerns that are uniquely presented by DNA print technology. Courts have no power to mandate quality assurance standards for forensics laboratories. Considerations of criminal justice issues not raised in the case at bar, such as fourth amendment issues, sharing of information, or indigent access, are normally outside of the court's admissibility inquiry. Novel scientific evidence has never before implicated similar concerns about individual privacy.

173. DNA printing is now beginning to be discussed by appeals courts with some regularity, although at this writing Andrews remains the only full-blown treatment of the technique's admissibility. In Kennedy v. State, 545 So. 2d 214 (Ala. Crim. App. 1989), the court not surprisingly rejected a death row prisoner's contention that his trial counsel's failure to have a DNA test performed-in 1980, several years before the technique's development-constituted the denial of effective assistance of counsel. The court observed that while at least nine states, including Alabama, had admitted DNA evidence at trial, only the Florida appeals court, using a relevancy standard, had ruled on the test's admissibility: "Thus, even if [the test had been available in 1980-81] we cannot say that the test would have been admissible at that time under the [Frye doctrine] which Alabama ... follow[s]." Id. at 218.

In Yorke v. State, 315 Md. 578, 556 A.2d 230 (1989), a convicted rapist filed a motion for a new trial on the grounds that new evidence unavailable at the time of his trial-the results of a DNA print test by Cellmark Diagnostics-exculpated him. The Yorke court affirmed the hearing judge's denial of the motion, but on the legal point that the new evidence-Yorke's DNA was not found in a post-rape vaginal washing from the victim-was not substantially likely to have produced a different result. The problem with Yorke is that at no stage did the technique receive an in-depth examination. At the hearing, the state did not object to or contest the DNA evidence. Finding the technique admissible, the judge noted that the issue would not be decided in this case, because of the state's failure to contest it, saying: "They are going to be using the test probably more than the defense as they get going ...." Id. at 584 n.3, 556 A.2d at 233 n.3. In turn, the Court of Appeals chose not to decide the pure admissibility issue until some other case brought it properly before them as a contested matter. Id.

In a recent decision an Ohio appeals court held that a defendant's religious objection to having a blood sample taken for DNA printing could not prevent the sampling. State v. Biddings, - Ohio App. 3d -, - N.E.2d -, No. 88AP-910 (Oct. 14, 1988, 1988 Ohio App. LEXIS 4179). The defendant, charged with rape, argued that a court order compelling the blood sampling violated his constitutional right to freedom of religion. The court centered its inquiry on the genuineness of the religious objection, finding little substance thereto. "Even if we accept [an] honestly held religious belief," the court opined, the state's compelling interest in making an identification in the case would outweigh the defendant's religious objection. Id. 
Courts, therefore, have had no reason to consider privacy issues in an admissibility hearing.

The legislature is better suited than either courts or crime laboratories to create a quality assurance regime for forensic DNA printing. This is partly because courts and laboratories are likely to refuse the responsibility, but primarily because the legislature in its capacity as a state's authoritative representative body is best positioned to balance the views of competing interests and to enforce a program of control. Legislatures are able to conduct hearings on policy and gather information from many sources. A legislature also has the power to transform policy into action by instituting and funding programs. The variety of issues and competing interests involved in DNA printing and the large number of citizens who could be affected are best accommodated by elected representatives.

A real question exists as to the inclination or ability of courts to require quality control prograins prior to adinitting forensic DNA printing. Courts are not likely to step into the regulation debate themselves. Their reluctance is illustrated by the recent case of People v. Reilly, ${ }^{174}$ in which a California appellate court held that electrophoretic analysis of bloodstains was generally accepted by the scientific cornmunity. In Reilly, an expert in biochemistry and forensic serology testified that, while electrophoretic bloodstain analysis had proven reliable in the hands of "competent, well trained and educated analysts who read the literature and adhere to established procedures," the failure of crime laboratories to adopt umform quality assurance standards should militate against the adinission of the procedure as evidence. ${ }^{175}$ The court responded:

The only conflict is that [the witness] intractably demands guidelines while his colleagues do not. Thus, the technique is generally, even overwhelmingly, accepted in the scientific community without the guidelines. As [the witness] concedes, guidelines cannot remove the risk of error altogether. We see no reason to judicially impose a "guidelines" requirement when the general scientific community clearly does not. ${ }^{176}$

The Reilly court thus continued to restrict itself to the narrow issue of the technique's general acceptance, declining to inpose quality control standards upon the industry judicially.

Despite the rhetoric of the Reilly court, the "intractable" witness in that case is not alone in urging that forensics laboratories implement a uniform quality assurance regime. Some forensics practitioners have recominended the adoption of quality control standards for crime laboratories. The Reilly court itself noted that an expert witness for the

174. 196 Cal. App. 3d 1127, 242 Cal. Rptr. 496 (1987), rev. denied, 46 Cal. 3d 779 (1988).

175. Id. at 1150,242 Cal. Rptr. at 511 .

176. Id. (emphasis in original). 
prosecution, a city crime laboratory director, had been a member of a national committee that created and proposed a recommendation for laboratory certification, and was the executive secretary for a voluntary laboratory accreditation program. ${ }^{177}$ Another prosecution expert witness had been "involved in unsuccessful efforts toward voluntary quality control procedures and certification." 178

The Reilly decision and the failure of voluntary certification and accreditation efforts suggest that neither courts nor the majority of laboratory personnel feel compelled to implement prescriptive quality assurance guidelines. A uniform program of analyst trammg (im each different system), however, is clearly desirable for DNA printing. In the absence of leadership from the courts or the forensic profession, the legislatures must provide the impetus for such requirements.

\section{B. Suggested Action}

Legislatures should regulate the forensic use of DNA prints. At least one state legislature has taken a step in this direction. ${ }^{179}$ The lawmakers should move on five fronts: review of the technique's scientific validity, quality assurance, fairness to defendants, due process, and privacy concerns. While the conditions for action may vary from state to

177. Id. at 1147,242 Cal. Rptr. at 509.

178. Id. at 1146, $242 \mathrm{Cal}$. Rptr. at 508 .

179. In October 1988 a New York state assembly panel conducted a day-long hearing about forensic DNA printing. Witnesses included representatives from Lifecodes, Cellmark Diagnostics, the state police crime laboratory, the FBI, professors, and scientists. Among other events, Professor Barry Scheck of the Cardozo Law School vehemently criticized the judge in Wesley-Bailey, who was also in attendance, for his admission of DNA printing, for setting himself up as a scientific peer review, and for basing his ruling on "incomplete" validation studies of the Lifecodes system. New York State Considers Legislating DNA-Fingerprinting for Forensics, supra note 54, at 8.

The outcome of this hearing is not yet clear. However, the legislative panel decided to consider funding a DNA print laboratory for the state police and to consider creating a "file" of the DNA prints of certain convicted felons, such as sex offenders, for future police use. The presiding legislator at the hearing, Assemblyman Terence M. Zaleski, noted the complex legal issues raised by the test, and told the press that another hearing on DNA printing might be held in 1989. Valhalla Lab Specializes in New Forensic Test, N.Y. Times, Dec. 11, 1988, § 12WC, at 1. The composition and scope of the New York hearing process provides one model for a potential legislative approach to the problem.

In the Spring of 1989, Professor Scheck and attorney Peter Neufeld, of New York City, challenged the reliability of the Lifecodes technique as applied in the investigation for murder of a suspect named Joseph Castro. Lifecodes representatives testified to a 100 million-to-one likelihood that bloodstains on Castor's watch matched the victim's blood, on the basis of DNA printing. However, four expert witnesses at the evidentiary hearing, including two of the prosecution's witnesses, issued a statement that "overall, the DNA data in this case are not scientifically reliable enough to support" the theory that the bloodstains came from the victim. The scientists criticized inconsistencies in interpretation and failures to convey further verifying experiments.

The pretrial evidentiary hearing concluded in May, with a ruling from the New York State Supreme Court expected for June. Lifecodes has stood by its testing. Anticipating victory, the defense attorneys expect to reopen all convictions involving all DNA testing by Lifecodes. Schmeck, DNA Evidence Faulted in a Bronx Murder Case, N. Y. Times, May 25, 1989, 14 Col. 1. 
state, and the technology of DNA printing will continue to advance, some general recommendations are still relevant.

The legislative approach should begin with a careful assessment of scientific validity of forensic DNA printing. Such an assessment would assist courts in considering empirical challenges to the technique. Legislatures should enact quality assurance standards to reduce errors and promote confidence in DNA test results. Finally concern for the rights of the individual should inspire procedural safeguards to ensure fairness and confidentiality rules to protect privacy. The following sections will outline one possible legislative course of action.

\section{Review of Validation}

Legislatures should appoint panels of disinterested scientists to review the facts about forensic DNA printing and report on their findings. ${ }^{180}$ The panelists should ideally be recruited from the disciplines of genetics, molecular biology, and biochemistry. To the extent possible, they should have experience with DNA printing and evidentiary stain analysis. At a minimum, they should have a solid academic or practical understanding of the special problems of testing forensic samples. The panel should review all published scientific reports on the extant DNA print techniques, and if possible, should visit the testing laboratories to observe the testing first-hand. Their report should discuss any apparent or potential deficiencies in the validity of each technique for forensic purposes.

A national commission with the same qualifications and assignments might be superior to state commissions for three reasons: (1) it would reduce duplication of effort, (2) it would enable less-populous states, whose fiscal and human resources might not make the state commission approach viable, to benefit from the scientific panel's research, and (3) it could draw on the best experts from around the country, making its final recommendations more persuasive. Precedent for such a national commission exists in the field of voiceprinting. ${ }^{181}$ Professor Giannelli lists the advantages of a scientific commission (which he calls "the radical approach" to reviewing scientific evidence) as follows: (1) scientific evaluation will be organized and not haphazard, (2) the evaluators would have had no financial or professional interests in the technique, and (3) rather than a blanket veto of an insufficiently validated

180. "Disinterested" in this context means having no financial or professional stake in the success of any DNA printing method.

181. At the FBI's request, the National Aeademy of Sciences reviewed voiceprinting technology and produced a comprehensive report. Giannelli, supra note 26 , at 1232 \& n.2. 
new technique, the scientific panel could recommend avenues for future research. ${ }^{182}$

Using the results of the expert evaluation, the legislature will decide what technique(s) should be used in the state's crinie laboratories. Although conınissioned by the legislative branch, the review obviously will be nost helpful to courts in determining the admissibility and weight of DNA printing inethods.

\section{Quality Assurance}

To safeguard the perforinance and evidentiary value of DNA printing, legislatures niust regulate crinie laboratories' performance. Such regulation inay involve DNA printing alone, or it inay be part of a niore general scheme of regulation of crime lab activity. Regulation nust center on quality assurance, operator training, operator certification, and accreditation to perform the test.

One potential problem with any regulatory systen is that inany states use DNA laboratories located outside their jurisdiction. States without DNA laboratories may, however, be able to condition their use of a particular laboratory's systein on the adoption by that laboratory of standards approved by the state legislature.

\section{Fairness}

State legislatures should create safeguards for crininal defendants in any legislative or regulatory schene involving DNA printing. Indigent defendants who can demonstrate a valid need for DNA printing services should receive them without cost. Forensic investigators should be required to save enough niaterial to allow the opposing party to have an alternative test performed. The prosecution should be required to share full inforination about its DNA print testing, including not only the final result, with a copy of the print itself, but all notes taken during the procedure and other inforination pertaining to the conduct of the test. The penalty for failure to allow discovery of this inforination could be to bar the prosecution's use of its test results as evidence.

\section{Privacy}

Finally, legislatures must realistically consider the threat to privacy that could result fronı abuses of DNA printing inforination by government agencies and private parties. The issue of individual privacy transcends the crinimal justice context and affects the whole of society. Confidentiality standards protecting against invasions of privacy nuust be part of the unitary package of legislation created by the legislatures.

182. Giannelli, supra note 26, at 1232. 
Because examiners can "read" so much personal information from DNA, and will be able to "read" even more in the future, legislatures must prohibit government agencies from establishing DNA print identification banks of the general population. ${ }^{183}$ Since a DNA print can be made without the subject's knowledge-from a hospital blood sample, an extracted tooth, or even hair off a hairbrush-the legislature should prohibit the unauthorized obtaining of DNA prints. Access to DNA print databases should be limited to law enforcement uses. Finally, legislatures must anticipate and prohibit abusive applications of DNA printing in the private sector.

\section{A Uniform Code}

The same efficiency considerations that support the creation of a national commission to review the scientific status of forensic DNA printing also support a "Uniform DNA Printing Code." This code would be similar to other uniform acts and model codes in intent. The obvious agency to carry out such a task would be the National Conference of Commissioners on Uniform State Laws. ${ }^{184}$ This body has already created uniform laws in the areas of marriage, drug and alcohol testing, and paternity, all subjects which seem to share common privacy and personal characteristics with DNA printing. A code along the same lines for the employment of DNA printing would certainly be useful to legislatures.

\section{CONCLUSION}

This Comment recommends a unitary legislative approach to regulation of forensic DNA printing in order to address concerns involving proof of reliability, quality assurance, fairness to criminal defendants, and threats to individual privacy. It proposes governmental creation of scientific review panels, quality control guidelines for crime laboratories, and enactment of necessary fairness and privacy statutes.

These recommendations are not designed to prevent the forensic use of DNA print technology, but to ease the entry of this revolutionary

183. At the New York legislative hearing, an FBI laboratory director/supervisor suggested that, with a nationally standardized testing system, a DNA data file could be used to track criminals across districts or to identify bodies, missing children, or military personnel. But a state assemblyman strongly objected to this idea: "They'll analyze my cells at birth, and Big Brother will watch me for the rest of my life." New York State Considers Legislating DNA-Fingerprinting for Forensics, supra note 54.

184. The National Conference of Commissioners on Uniform State Laws tries to promote "uniformity in state laws on all subjects where uniformity is desirable and practicable." Proposals of subjects for model legislation are referred to a standing subcommittce which decides whether it is "appropriate for attention by the conference, in keeping with specific criteria." If it is, a special ad hoc committee prepares a series of drafts of a model act. 9 U.L.A. Pt. II, at iii (1988). 
forensic method into the legal system. There is obvious tension, however, between this Coinment's ultimate acceptance of DNA prints as valid evidence and its immediate call for further inspections and rulemaking, which inay produce delays. This type of tension will reoccur whenever coinplex and novel scientific methods are applied to criminal detection and prosecution. In a sense, then, the present controversy over DNA printings foretells future controversies over powerful new forms of scientific evidence. Perhaps the adoption effort this Comment recominends can serve as a inodel whenever a new scientific method provokes similar, dichotomous concerns over its unsurpassed accuracy and unparalleled intrnsiveness. 
